\title{
Capítulo 2 \\ Mujeres campesinas, mujeres muiscas: relatos de vida en torno a la indigenidad
}

\section{Imágenes-recuerdo e imágenes-hábitos: ejes narrativos y discursivos de la memoria muisca}

El presente capítulo puede considerarse como el centro de nuestra reflexión general, puesto que pretendemos explicar la relación existente entre la indigenidad y la memoria muisca que se produce desde los marcos narrativos y reflexivos de mujeres indígenas de Bogotá. Las múltiples conversaciones etnográficas y algunas entrevistas en profundidad con tres mujeres que hacen parte de las dos comunidades muiscas actualmente reconocidas en la ciudad nos llevaron a preguntarnos si al relatar acontecimientos del pasado dichas interlocutoras elaboraban memorias, o si acaso sus actos de habla se relacionaban con el discurso que en la actualidad sustenta la identidad étnica de ellas mismas y de sus comunidades. Por ahora podríamos afirmar que ambas cosas sucedían.

Respecto a la memoria, la respuesta parece más fácil de elaborar - por supuesto las mujeres muiscas elaboran memorias a partir de sus relatos del pasado- aunque requiere de algunas reflexiones claves. La primera de ellas corresponde a la tipificación de la memoria 
(o memorias) que se elabora(n) a partir de los relatos compartidos por las mujeres. ¿De qué tipo de memoria hablamos cuando hablamos de memorias de mujeres indígenas? En los actos de habla cotidianos de varios líderes y miembros de las comunidades muiscas emergen conceptos como "memoria ancestral", "memoria tradicional", "memoria indígena”, e incluso "memoria” a secas.

Por otro lado, en el marco de nuestras redes de investigación sobre temas de memoria, los procesos estudiados acá suelen tipificarse como "memoria cultural" y diferenciarse de otras memorias que en las coyunturas actuales hacen parte de los proyectos de verdad, reparación y garantías de no repetición propios de escenarios de conflicto armado y justicia transicional. ${ }^{1}$ Con base en tales discusiones, calificar de "cultural" una memoria implica caracterizarla como de largo aliento, reposada en prácticas y repertorios más que en archivos y con repertorios corporales (rutinas, actos de habla, comportamientos, ademanes y performances) más variados que no la localizan específicamente en los escenarios de la oralidad.

La segunda reflexión en torno a la tipificación de la memoria, derivada de la anterior, nos llevó inevitablemente a la revisión crítica de la diferencia que pensadores clásicos han dado entre la memoria cultural y otras como la "memoria comunicativa". Es pertinente, entonces, referirnos a las teorías elaboradas por Jan Assman (1995), no sin antes proponer cómo nuestro trabajo de campo las puede confrontar.

El 28 de julio de 2015, en la sede de la Casa de Medicina Zhue Gata, ubicada en la plaza central de Bosa, se llevó a cabo un encuentro de indígenas muiscas de Bogotá. Alrededor de la comida (sopa, aguacate y papas), el espacio buscaba motivar una conversación muy

1 Nos referimos, y agradecemos de antemano, las conversaciones con el profesor Alejandro Castillejo, quien como director del Programa de Estudios Críticos de las Transiciones (Pect) nos invitó a ser parte de redes de discusión académica que permitieron identificar a la por ahora llamada "memoria cultural" como un campo de producción y acción social poco tenido en cuenta en los escenarios transicionales actuales en el país. De igual forma aparte de su producción académica contribuyó a alimentar nuestras reflexiones frente a este punto. Ver Castillejo (2009; 2013a; 2013b) 
familiar en torno a las historias compartidas por tres "mayoras" de la comunidad de Bosa: Cecilia, Inés y Nancy. De esa manera, el recinto central de la casa se convirtió en una gran sala dispuesta a una audiencia para escuchar historias de antaño. Sin embargo, dicha familiaridad fue complementada con un inicio que tuvo visos de cierta formalidad y ritualidad. Yilena, mujer joven de la comunidad de Suba, tejedora, actuó como vocera principal del sencillo evento. Como pasa siempre en los encuentros de las comunidades muiscas, agradeció a Padre y Madre, creadores del cosmos, y a los espíritus del territorio que nos acobijaba en ese momento.

Seguidamente, como también suele ocurrir paulatinamente en este tipo de escenarios, Yilena con sus palabras comparaba los procesos de recuperación cultural y étnica muisca con un concepto compuesto de una imagen contenedora de acción y lenguaje: "caminar la palabra”. De esta manera, los procesos de aprendizaje devenían caminos, vivencias, transformaciones, y los conocimientos adquiridos se articulaban en el pensamiento, el corazón y la voz de los individuos y del colectivo. Entonces, la ceremonialidad de su discurso se transformó en lo que cotidianamente conocemos como tono anecdótico: comentó que Barbarita, otra mujer presente, contó que cuando había visitado el humedal de Chiguasuque por última vez, en el camino de entrada vio a un hombre que no era ni anciano ni joven, vestido de blanco, con gorro y mochila, parado al lado de un eucalipto. Yilena no estuvo presente, pero como contadora de la historia parecía vivir en carne propia el recuerdo - es lo que más adelante denominaremos metamemoria-. Decía que tal hombre simplemente las observaba mientras caminaban, que las saludó y sintieron que les daba la bienvenida al territorio. Siempre lo vieron supervisando cualquier actividad que realizaban. En palabras de Yilena, sentían que el hombre aprobaba el trabajo llevado a cabo por las mujeres ese día y que con eso permitía seguir "abriendo el camino".

En resumen, dicha persona o entidad era la materialización humana de un espíritu guardián y ancestral que otorgaba el permiso de ingreso y trabajo en ese lugar; auguraba éxito en la empresa llevada a cabo en dicho territorio. De lo anecdótico, Yilena nuevamente 
volvió a lo metafórico y complejo, pues resaltó que era importante que cada uno/a pusiera "algo en el tejido", es decir, que mediante su palabra (preguntas, historias, anécdotas, pensamientos y reflexiones) aportara a eso que los muiscas de hoy consideran su conocimiento colectivo. Agradeció nuevamente al territorio de Chiguasuque y a la serpiente como camino de este territorio, en honor a la Madre Bachué, de tal forma que la constelación formada por Chiguasuque-SerpienteBachué reveló tres "imágenes-hábitos" propias del recordar muisca contemporáneo.

Si retomamos algunos elementos del breve relato etnográfico, podemos revisar críticamente dos tipos de memoria diferenciados por Assman: la "memoria comunicativa" y la "memoria cultural".

La memoria comunicativa comprende a nivel general todas las variedades de la memoria colectiva basadas exclusivamente en las comunicaciones del día a día, constituye el campo de la historia oral y se caracteriza por operarse bajo un alto nivel de no especialización, así como por la inestabilidad temática (Assman, 1995). En esta memoria todos caben: cualquier sujeto comunicante y social participa, los expertos y los no expertos, los dominantes y los marginados, las voces oficiales y las no oficiales. Sucede en lo que Assman (1995), siguiendo a Thomas Luckman, denomina communicative household, es decir aquellos lugares y espacios cotidianos (vías del tren, salas de espera, mesas comunes- incluiríamos casas de familia y escenarios de reunión colectivos informales) donde se comparten todo tipo de experiencias, hasta chistes y bromas que pueden ser parte de los marcos de "iniciación societal" que se repiten constantemente.

Eso era precisamente lo que notábamos en la casa de medicina de Bosa: unas experiencias compartidas que hacían parte de los marcos referenciales comunes de los muiscas reunidos. Aunque variados y dispersos, los actos de habla de los participantes tendían a resaltar las mismas figuras literarias, los mismos conceptos, los mismos tonos y las mismas constelaciones de imágenes. Era un escenario de despliegue de la memoria comunicativa que presentaba dos tipos de recuerdo caracterizados por Maurice Halbwachs en los mismos contenidos de los relatos. Por un lado, “recuerdos-imágenes”, es decir imágenes 
"localizadas en un momento definido" del pasado (Halbwachs, 2004, p. 35); pues las historias de las mayoras reproducía eventos y lugares sucedidos décadas atrás que procuraron ser reproducidos en sus relatos. Más adelante veremos que tales lugares "comunes" marcan una tendencia de marcadores y referentes espaciales de la memoria individual y colectiva como la casa en que se nació y creció, las jornadas de trabajo comunitario, las fiestas, la comida, los paisajes, etc.

Por otro lado, la tendencia a aparecer de manera reiterada hizo que también fueran "recuerdos-hábitos", es decir, que no aparecen una sola vez, sino que "provocan en nosotros ese sentimiento de familiaridad que acompaña la percepción de objetos o de personas con las cuales tenemos relaciones frecuentes" (Halbwachs, 2004, p. 34). En suma, las imágenes transmitidas por los relatos marcaban tanto acontecimientos específicos como habituales y generalizados en el grupo de contadoras de historias y su audiencia.

Sin embargo, no podemos negar que también se percibió un ambiente de formalidad, ritualidad y ceremonia, y que de igual forma ciertas imágenes arquetípicas fueron reiteradas en los discursos: la Madre, el Padre, la serpiente, el camino, la medicina, los espíritus, la diosa Bachué y la laguna, entre otros, hacen parte de un repertorio de lo que Assman (1995), siguiendo a Aby Warburg (1987), denomina “objetos de la memoria", pues en su vivencia y referencia se activa la "contemplatividad retrospectiva" (retrospective contemplativeness) y la "energía mnemónica” (mnemonic energy) típica de los objetos de los museos, los monumentos y las figuras totémicas. Dicha formalidad y cristalización de los recuerdos colectivos hacen parte de lo que Assman (1995) denomina en sí "memoria cultural".

La memoria (o memorias) que emergió en el convite de la casa de medicina se localiza en los intersticios de la memoria comunicativa y la memoria cultural. A primera vista, la espontaneidad e informalidad caracterizaron las anécdotas compartidas por mujeres sencillas que transmitieron sus relatos de vida. No había rigurosidad ni una estructuración de los relatos que llevara a considerar como "expertas" a dichas mujeres. Sin embargo, al profundizar el análisis y revisar el contenido de tales relatos se pueden identificar tendencias y reiteraciones 
a la hora de transmitir paisajes, figuras, objetos, jerarquías, roles y prácticas. Tales rasgos se tornan objetos y figuras de la memoria que son de cierta manera definidos y diferenciados por el colectivo como referentes de su identidad y las mujeres contadoras de historias, en consecuencia, son legitimadas por el grupo como "voces oficiales" del pasado. De esta manera, los recuerdos-imágenes, los recuerdos-hábitos y los objetos de la memoria presentes en el contenido de los relatos permitieron que la familiaridad de los recuerdos, mediante la reiteración, devinieran en referentes comunes y estructurales de la memoria del grupo. Transitaron de la informalidad a la cristalización.

La segunda respuesta, respecto a la relación entre los relatos y los discursos contemporáneos de la identidad indígena también merece cierta reflexión. Para Marisol de la Cadena, la identidad indígena se compone tanto de relaciones intersubjetivas que definen al indígena y al no indígena, como de producciones discursivas y "políticas conceptuales" que validan e invalidan los criterios de definición étnica de acuerdo a las circunstancias históricas (De la Cadena, 2006; De la Cadena y Starn, 2009).

De esta manera, las mujeres que relatan no solo comparten sus recuerdos, sino que además alimentan su oralidad de discursos en torno a su identidad indígena. Sin embargo, esto se da paulatinamente en la medida que sus vivencias avanzan de las imágenes recuerdos y hábitos de la niñez y juventud hacia las enmarcadas en la organización social indígena. En entonces cuando de las historias habituales en torno a la vida campesina y comunitaria sabanera los relatos se complementan con reflexiones sobre la manera en que asumieron la conciencia de diferenciarse social y culturalmente de la población mestiza mayoritaria y asumir la identidad como miembros de comunidades indígenas contemporáneas. Y pese a que estamos de acuerdo con Laclau (1987) al afirmar que no existe ningún discurso que vincule a priori la identidad indígena o de clase social con posiciones definitivas y cerradas en torno a los problemas políticos, sí se identifican tendencias en los relatos y posiciones de las mujeres.

Entonces nuevamente las imágenes se tornan habituales y comunes para recordar cómo transitaron de una identidad campesina hacia 
una indígena. Por supuesto, las imágenes también alimentan los tropos y metáforas - no solo poéticas sino políticas- del rol de la mujer y del "poder femenino" en los procesos organizativos étnicos del altiplano cundiboyacense.

Este capítulo, entonces, precisamente se basa en identificar el rol que cumplen tales imágenes transmitidas oralmente por las mujeres en la conformación de la memoria comunicativa y cultural muisca, así como en la indigenidad contemporánea. Para ello se trabajó principalmente con tres mujeres muiscas, dos de la comunidad de Bosa y una de la comunidad de Suba. Cecilia Chiguasuque hace parte de la primera y es considerada como una "mayora" importante en los procesos de rescate de la medicina y la llamada "espiritualidad" muisca. Lidera los procesos llevados a cabo por la casa de medicina Zhue Gata de Bosa. Cecilia Neuta de Bosa es una mujer mayor que hizo parte del grupo de contadoras de historias en el evento referido líneas atrás. Su acercamiento con los procesos de medicina son pocos, pero representa a las fuentes primarias que las nuevas generaciones de líderes muiscas de Bosa han consultado para recopilar historias y referentes campesinos que luego son interpretados como base de la identidad indígena contemporánea, o lo que Pablo F. Gómez M. denomina "la indigenización del campesino" (Gómez, 2015).

Por último Dioselina Triviño, quien es recordada como mujer que hizo parte de la organización de familias que comenzaron el proceso de recuperación de tierras que dio origen al actual Cabildo Indígena Muisca de Suba. Enfermera de profesión, Dioselina fue autoridad del cabildo y es madre de otra mujer que alguna vez fue gobernadora durante tres periodos.

Además de registrar en audio los relatos transmitidos en la casa de medicina, se acudió a la entrevista abierta y a la conversación etnográfica con el fin de elaborar relatos de vida de estas mujeres e identificar los ya nombrados "recuerdos-imágenes" y "recuerdos-hábitos". Con el análisis y sistematización, se identificaron en las trayectorias de vida de estas mujeres los recuerdos y referentes que configuran en la actualidad su indigenidad muisca, es decir, la manera de elaborar discursiva y prácticamente su identidad como indígenas, proceso en 
el cual participan además otros actores como la sociedad general, las instituciones estatales, otros pueblos indígenas y sus mismos vecinos.

Preferimos no presentar cada historia de vida por separado a manera de una compilación de relatos, sino de forma integrada y organizada en categorías que fueron elaboradas a partir de los mismos referentes narrados. En primera instancia, la narrativa que integra los relatos se divide en dos horizontes. De un lado, el horizonte del pasado campesino, nativo, de la niñez y la vida bucólica que aporta las imágenes y referentes de un estilo de vida que hoy día es definido como indígena en la elaboración discursiva de quienes en el presente se autorreconocen como muiscas y buscan basar su identidad étnica en "usos y costumbres" que, insistimos, fueron considerados como "campesinos" por las relatoras. Por otro lado, la narrativa se hila por medio de los relatos sobre el rol de las mujeres en la conformación de las organizaciones familiares indígenas que defendieron los territorios y que dieron origen a los cabildos indígenas de la actualidad. Ahí la discursividad cambia, la palabra indígena se apropia y, con ella, se transforman las posiciones de sujeto de las mujeres.

En segunda instancia, cada horizonte fue organizado mediante subcategorías también definidas desde los mismos relatos y corresponden a lugares, usos, costumbres y eventos cotidianos e históricos que marcan referentes de esa memoria muisca que oscila entre lo comunicativo y lo cultural ya definido, así como puntos de giro en la conformación discursiva de la indigenidad de estas mujeres. En otras palabras, la narrativa integrada de las mujeres se organizó a partir de imágenes-recuerdo e imágenes-hábitos.

En últimas, mediante estas historias de vida, se comprenden las maneras como estas mujeres se identificaron como indígenas, con lo cual se afirma desde este trabajo que, aunque fundamentada en elementos que han pervivido desde la ruralidad bogotana, la identidad indígena muisca es transitoria y reelaborada discursivamente. El grado de identificación, así como las prácticas que sustentan dicha indigenidad se afirma y ratifica con los cambios de roles que estas mujeres van narrando. De esta manera, ser mujer muisca se transforma mientras se transita por el rol de hija, esposa, madre, trabajadora, ama de casa, líder comunitaria o mujer de medicina. 


\section{Primer horizonte: el pasado campesino de los "nativos" de Bosa y Suba}

\section{Linaje, lugar de nacimiento y primeras cartografías}

A partir de los relatos de vida de Cecilia Chiguasuque e Inés Neuta, indígenas de Bosa, y Dioselina Triviño, indígena de Suba, pudimos identificar que como mujeres asumen un rol de contenedoras y transmisoras de memorias cotidianas enmarcadas principalmente en la familia. Las características de sus ancestros y las historias transcurridas alrededor de la casa se convierten en el punto de referencia de sus primeras memorias. Dicho rol exige, entre otras, la competencia de recordar los apellidos de dos generaciones anteriores: de sus padres y abuelos. Una vez reelaboran la cadena generacional hasta ellas, el ejercicio de asociación de ideas las conduce a relacionar sus linajes con una presentación inicial del lugar específico en que nacieron y vivieron la mayor parte de su infancia. De esta manera, linaje y territorio comienzan a forjar una primera cadena de referentes que fundamentan las imágenes-recuerdos.

La elaboración de la memoria comienza a verse como una elaboración cartográfica, no solo porque los recuerdos emerjan asociados con elementos del paisaje y lugares localizados de manera específica, sino porque "tejen" -tropo fundamental en el mundo oral indígena de hoy- relaciones diversas entre elementos heterogéneos. Tales relaciones y constelaciones se tornan interesantes para el analista cuando brindan informaciones que se caracterizan por establecer vínculos entre estructuras históricas y la vida cotidiana.

En el caso de Cecilia Chiguasuque y Dioselina Triviño, sus relatos comienzan, de manera esperada, con el nombramiento de sus linajes. A diferencia de relatos elaborados por personas nacidas en ambientes urbanos y contemporáneos, la historia personal siempre va referenciada inicialmente con la del grupo familiar. No es una memoria egoísta y narcisista, pero que sí busca mostrar, por parte de la mujer indígena, su capacidad de relacionar su linaje con el mundo social. La diferencia entre Cecilia y Dioselina ocurre en las cartografías elaboradas, pese a que ambas muestran dicha capacidad nemotécnica. 
Cecilia establece relaciones entre el apellido de su padre y las relaciones de subordinación laboral con la figura del patrón, en este caso un capitán del ejército, dueño de una de las grandes haciendas de Bosa. La ambivalencia entre la sumisión y el agradecimiento, el servilismo y la familiaridad, que en el relato de Cecilia hace que la familia adinerada sea nombrada de manera tan cercana a la propia al tiempo que ocupando un lugar claro de poder, permite que el criterio cartográfico permanezca. Por esta razón, para Cecilia es inevitable que una vez elabora el árbol genealógico de su familia, no elaborar un paralelo con el linaje del hacendado respecto a la reproducción de la relación laboral de servilismo.

Yo nací en Bosa. Mi papá se llamaba Jerónimo Chiguasuque Fonseca. Mi mamá se llamaba Evangelina Tunjo Tunjo. Mi abuela paterna se llamaba Mercedes Fonseca y mi abuelo Venancio Chiguasuque. Mi abuelo materno se llamaba Ricardo Tunjo y Manuela Tunjo. Somos oriundos de este territorio. Tengo seis hermanos, yo soy la cuarta.

Mi padre por lo general siempre fue administrador de hacienda y trabajó muchísimos años con un capitán que se llamaba Luis Eduardo Ángel Tamayo, él era un capitán retirado de las fuerzas militares. Entonces él tenía una finca grandísima y la tenía donde hoy día es el Porvenir. Pero en ese tiempo se llamaba la hacienda el Corzo. Todos los seis hijos nacimos allí en esa casa, porque mi papá desde muy joven trabajó allá, el capitán le dejó una casa en la hacienda el Porvenir, ahí nos radicamos y ahí nacimos todos los hijos. Mi mamá los parió ahí. Y ya, con el tiempo todos crecimos, mis hermanas mayores estudiaron, aprendieron a leer y escribir que era donde llegaba el estudio, entonces el mismo capitán tenía hijas que eran profesionales todas. Las hijas del capitán se llevaron primero a mi hermana, después se llevaron a mi otra hermana, después seguí yo. Yo trabajé cuidando un niño de una hija del capitán. Nosotros salimos muy jóvenes de ahí (Cecilia Chiguasuque, comunicación personal, agosto 18 de 2015). 
La cartografía de Cecilia marca la división social del trabajo: las hijas del mayordomo serían las empleadas domésticas de las hijas del hacendado. El caso de Dioselina Triviño marca una diferencia en la medida en que en sus memorias los terrenos del sector hoy conocido como el Rincón de Suba eran propiedades de las mismas familias nativas. Consecuentemente, Dioselina complementa el relato con un discurso sobre la identidad: su familia como otras eran "nativos". De ahí, además, que su cartografía relacione apellidos con marcaciones territoriales específicas.

Mi papá era José Obdulio Triviño Neuta, los otros apellidos de mi papá yo no me acuerdo. Era de Zipaquirá. Bárbara Bulla Piracún, entonces los apellidos de mi mami Bulla Piracún Nivia Caita. Los apellidos de ellos eran totalmente nativos porque nunca se fueron de ahí y ahoritica vive toda esa gente; usted va a allá y ve en una cuadra los Triviño y en otra cuadra los Nubia, en otra cuadra los Zeas, los Yopasá, todos viven parcializados. Sumercé, eso de 'somos nativos', nada de 'somos indígenas, somos chibchas o muiscas', esas palabras no salían. Mi mamá no decía que era indígena, sino que era nativa: 'nosotros somos nativos, nosotros nacimos acá'. Ella llegaba y se sentaba al pie del fogón, 'nosotros nacimos acá y acá tenemos que morirnos'. Nosotros nacimos acá, nosotros acá nos criamos, acá comimos, todos los de mi familia somos de acá.

Nosotros vivíamos en la laguna por donde ahora queda la novena, la laguna en el charco de donde queda el camino de la vereda, por donde queda la avenida Cali, en la laguna de Tibabuyes. Hacia ese lado vivimos, no hacia el Quirigua, sino hacia esa zona, en donde está la casa materna, ahí (Dioselina Triviño, comunicación personal, septiembre 15 de 2015).

Ambos relatos muestran que el linaje y el territorio originario se ligan para conformar un primer lazo identitario, así como una cadena asociativa de recuerdos. Como elemento común entre ambos relatos, cada mujer tomó como punto inicial de referencia la casa de un 
ancestro. Pero mientras Cecilia se basó en el linaje patriarcal, propio de Occidente, Dioselina en el matriarcal, figura más cercana a lo que conocemos culturalmente de los muiscas antiguos.

\section{De la metamemoria a la memoria: la casa y los referentes bucólicos}

Una vez las relatoras parten de sus referentes ancestrales, dos elementos emergen a continuación. En primer lugar, que los recuerdos narrados no corresponden a momentos que pueden testificar, sino a vivencias transmitidas. Este dato demostraría la capacidad que las mujeres muiscas entrevistadas no tienen solo de escucha, sino de fundamentar su propia vida en sucesos anteriores a esta. Es relevante resaltarlo, ya que la categoría "ancestral" o "memoria ancestral" muchas veces queda ligada en este tipo de estudios a los grandes mitos y relatos heroicos, cuando los indicadores más precisos se hallan en las historias de quienes antecedieron de una a tres generaciones a quienes hacen memoria.

En segundo lugar, la constelación de recuerdos transmitidos se complementa con detalles que en primera instancia son interpretados como de "vida campesina", no como "indígena". Este dato es de suma importancia, ya que permite comprender que la indigenidad se da discursivamente en el tiempo y se transforma con la historia personal y comunitaria. Sin embargo, en los relatos emerge la imagen de la pobreza y la austeridad, imagen que va a tornarse un valor y rasgo característico de la identidad indígena muisca contemporánea. De ahí que las imágenes de la casa sencilla, sin luz ni tecnología no solo describa el pasado, sino que busca marcar discursivamente la diferencia entre lo indígena - ligado a ese complejo de imágenes denominado lo "tradicional" - de lo no indígena, relacionado usualmente con lo moderno.

En el caso de Dioselina, la casa de la abuela y sus características de humildad y pobreza marcan la identificación con una vida sencilla y austera:

Mi mami nos contaba que los ranchos sí eran de bahareque y barro. En ese tiempo, digamos, por aquí había una familia y en el Carulla había otra familia y por allá en el río había otra familia, 
entonces las familias eran retiradas. Cada familia vivía retirada, pero todos eran conocidos. Ella siempre nos dijo que 'somos nativos' y yo le decía: 'mamá, pero ¿por qué dice que somos nativos?' Ella me decía que porque toda su vida la había vivido ahí, toda la familia, sus tíos sus abuelos eran de ahí y que por eso éramos nativos del territorio. Ella nunca dijo que indígenas y se molestaba y decía que nosotros no éramos indígenas, que éramos nativos.

Mi madre, mi mamá siempre nos decía 'en la casa no había gas', no había nada, la agua había que llevarla a la mala del chorro que quedaba cerquita de los lados de la vereda que va para Suba. Baja el agua pura de los lados de ese lugar, eso era de los amigos que vivíamos ahí, porque en ese tiempo siempre eran las mismas familias.

Nosotros en la finca cultivábamos el maíz, frijol, la papa. Usted acá veía potreros llenos de comida, solo fincas, solo campo. En el camino que sale de la 91, del Rincón a Suba, era un camino con unas zanjas grandes y las matas pegaban unas con otras. Era un camino de herradura, yo a los carros los vine a conocer a eso de los 8 o 10 años, todo lo que se sacaba era en mula. Mi mamá decía que le tocaba ir a pie hasta la plaza del Quirigua. Ellos hacían el cambio y ella llevaba el guán y con eso ella amarraba, lo usaban como lazo y eso tengo entendido que lo pisaban y lo llenaban de barro. Con eso amarraban para hacer las casas de bahareque y hacían el trueque (Dioselina Triviño, comunicación personal, septiembre 15 de 2015).

Dos elementos se destacan del relato de Dioselina. En primer lugar, la definición etic del concepto "nativos", que corresponde a las familias que "siempre" han estado en ese territorio. Más allá de la obviedad del término, nos muestra que al no haber memoria de familias foráneas o de orígenes diferentes, la historia de Suba contada afirma la permanencia generacional y la endogamia pese a la "no conciencia" de la identidad étnica diferencial. En segundo lugar, que el referente principal de Dioselina es el clásico comparativo “antes-después” propio de quienes desean marcar la diferencia de los tiempos vividos y resaltar las evidentes y marcadas transformaciones del espacio geográfico. 
A diferencia de la historia de Dioselina, la casa paterna de Cecilia no fue propia al inicio, sino que marca la condición laboral de su padre como peón y mayordomo de una hacienda, lo cual fue una característica común de varios hombres descendientes del Pueblo Muisca en la Sabana de Bogotá desde el siglo XIX hasta gran parte del XX. A partir de tal referente, Cecilia se une a la habitualidad de resaltar la identidad campesina de antaño y la no conciencia de la identidad indígena. Pese a eso, destaca la vida y el trabajo comunitario como rasgos característicos de las familias antiguas, rasgo que será profundizado más adelante.

En ese tiempo el trabajo de ellos era ir a limpiar los vallados, es el trabajo de todos. Porque nosotros en ese tiempo nos considerábamos era campesinos y todos sembrábamos ahí, ellos cultivaban, entonces cuando las siembras estaban listas entonces los llamaban de las haciendas pá que fueran a limpiar los vallados. Y mi papá era un contratista de eso. Entonces él llevaba también su gente que le trabajara y les hacía sus contratos. Entonces en ese ir y venir a él lo contrataron como mayordomo de la finca (Cecilia Chiguasuque, comunicación personal, agosto 18 de 2015).

Entonces tenemos que en primer lugar las relatoras apelan a una metamemoria, término con el que queremos afirmar que a veces se hace memoria de memorias. Es el caso tanto de Dioselina como de Cecilia cuando recuerdan lo que recordaban y transmitían sus padres. El paso siguiente en sus narrativas, es involucrarse como testigos de tal metamemoria. En el caso de Cecilia Chiguasuque e Inés Cecilia Neuta, sus roles de testigos permiten conformar una narrativa que encadena la casa paterna, la labor del padre y la colaboración como hijas, oyentes y ayudantes de trabajo. Tales narrativas vinculan y relacionan la imagen de una niñez llevada a cabo en un ambiente sano, localizada en esquemas familiares autoritarios. De esta manera los recuerdos de la dureza/sumisión se complementan con imágenes-recuerdos del trabajo agrícola y ganadero. 
Él me contaba por ejemplo de cómo llegó a trabajar en la finca, cuando lo llevaron los patrones, el cargo que él tenía, cuando yo le llevaba el desayuno me quedaba a ayudarle a soltar los becerros y eso era pa'l potrero, le ayudaba a limpiar las corralejas donde estaban las vacas que ordeñaban, le ayudaba a lavar cantinas. El almuerzo a veces tocaba llevárselo o a veces llegaba a la casa. Pero cuando era él el que se quedaba en la hacienda yo era la que le llevaba el almuerzo (Cecilia Chiguasuque, comunicación personal, agosto 18 de 2015).

A medida que avanzamos en las historias de vida, notamos que por lo general uno de los padres no solo es usado como referencia para tejer los recuerdos. Además marca vínculos sentimentales que permiten identificar pistas sobre la manera en que se desarrollaban las relaciones familiares y de género entre padres-madres-hijos-hijas. Cecilia ya destacó la relación cariñosa y de colaboración con su padre. Eso marca la ambivalencia entre la autoridad y el cariño, entre las figuras relacionadas con la felicidad de la niñez, y la sumisión y respeto que en la misma edad caracterizaba frente a la relación con los mayores.

Yo soy natal de acá de Bosa. Pues en esos tiempos, nuestras tierras eran muy bonitas, porque había muchas fincas, se cultivaba mucho el trigo, la cebada, el maíz, había muchos árboles. Uno como joven pequeño, hacía muchas travesuras, porque tenía donde divertirse, donde jugar, tenía sus árboles para los columpios, tenía sus animales, porque también a uno le tocaba muy duro, le tocaba a uno ayudarle a sus padres para ayudar a ver los animales, ellos tenían sus vacas. Entonces, así como uno disfrutaba de su tierra, de su finca, también los padres le daban a uno muy duro, porque tocaba ayudarles a cuidar las cementeras, las fincas, los animales, todo. (Inés Neuta, comunicación personal, julio 28 de 2015).

En el caso de Dioselina, su rol testifical está en referencia prioritaria al paisaje y al trabajo de recolección que por tradición los campesinos 
y descendientes de muiscas han realizado de recursos de los cerros y valles. El pasado lejano se narra con el tono de la niñez, la cual a su vez siempre va acompañada de imágenes paisajísticas que se presentan de manera positiva, prístina y bucólica.

Nosotros no teníamos frontera, teníamos potrero por todo lado, los cerros de la Conejera. En Semana Santa ellos se iban por allá y esos son los pagamentos que supuestamente ahorita hacen, es como el pensamiento. Se cepillaban los dientes con el arrayán. Nosotros íbamos donde don Jorge. Había nacimientos de agua y mi mamá, cuando iba a lavar, bajaba un ramo de arrayán. Yo conocí a mi mamá con las cargas de leña para la cocina porque cocinábamos en fogón de leña y la carne se compraba para toda la semana, o cuando mataban un animalito se ponía a secar la carne junto a fogón y no se sufría por comida porque siempre había (Dioselina Triviño, comunicación personal, septiembre 15 de 2015).

El leitmotiv de la abundancia, la vida sana y la tranquilidad emanada de un territorio limpio y no contaminado es característico de las narrativas de las mujeres mayores indígenas de la ciudad. Sus relatos siempre van a contrastar los tiempos (el pasado y el presente) y los espacios (lo rural y lo urbano); a nivel temporal todo lo "anterior" fue mejor y todo lo que trascurrió en el ambiente bucólico también. La alegría propia de la niñez va acompañada de la pureza de un río que hoy nadie imaginaría limpio y con vida.

Y se daba mucho el cultivo de papa, uno nunca aguantaba hambre porque se daba el cultivo de todo; de trigo, de cebada. Yo me acuerdo cuando yo era pequeña, mi papá me llevaba... ellos tenían tierras, me llevaban por allá a cegar. Yo no sé si los jóvenes sepan lo que es cegar, no creo. Entonces mi papá me montaba en la bicicleta y me decía: 'vamos para allá donde está el trigo, está la cebada y vamos a cegar'. Entonces nos llevaban, y cegar era una cosa así como un gancho y cogían el manojo así, porque no 
había máquinas, como las que ahora hay para recoger el arroz. En ese tiempo era puro a mano. Y eso ellos cogían así, y a uno lo llevaban, y tenía uno que aprender a amarrar el manojo de trigo, cebada o lo que fuera, aprenderlo a coger, así mismo amarrarlo e ir haciendo como gavilla e ir montando el trigo, la cebada. La pasaba uno hasta bien, buena comida. Lo mismo el río, el río era muy bonito, el río Tunjuelo, y que hoy en día esas aguas como pararán, como hoy en día ven ese río tan sucio y tan... En ese tiempo el río era muy bonito, uno cuando era pequeño lo llevaban a bañarse al río, eso era como playas de arena y lo llevaban a uno allá, por la mañana lo metían a uno a bañarse, uno se metía en la mitad del río y el agua pasaba por un lado y por el otro, los pescaditos pasaban por un ladito de los pies. Los cangrejos que tienen las paticas así, uno era feliz cogiendo esos cangrejos. Ellos cogían muchos pescaditos, se llamaban Guapuchas, eran así, chiquitititas, y ellos cogían mucha Guapucha. Las llevaban a secar por allá encima de los techos, porque qué nevera ni que nada, les echaban sal y las dejaban por allá encima de un tejado a secar, después las hacían con papas por encima, eso las tostaban con maíz y eso era rico. Yo recuerdo eso (Inés Neuta, comunicación personal, julio 28 de 2015).

Una vez se supera la metamemoria para comenzar el rol de testigos, las relatoras nos permiten identificar en sus memorias la manera como incorporaban una serie de usos, costumbres y valores a su biografía. Los apartados que se presentarán a continuación no solo tienen como objetivo catalogar una serie de elementos propios de la niñez de nuestras relatoras. En el marco del análisis contribuyen a identificar las bases culturales que en etapas posteriores de su vida van a resignificarse como propias del ser indígena, es decir que lo que en un inicio eran aparentemente simples imágenes-recuerdos del pasado más adelante se convertirán en ideas centrales del discurso de la identidad indígena; la indigenidad del campesino forjada a partir de imágenes habituales a las que se interpretarán y se asumirán significados indígenas en las circunstancias históricas que lo ameritaron. 
Quiere decir que en primera instancia la indigenidad es un discurso externo a ellas en su niñez, pues se identifican como campesinas. Luego los elementos caracterizados a continuación harán parte de referencias de una nueva discursividad contemporánea, que integrará usos y costumbres asumidos como muiscas hoy día.

\section{Autoritarismo de los padres}

Un elemento que se resaltó en el trabajo de campo en Bosa fue el autoritarismo de los padres de antaño, lo cual no sucedió en Suba, debido a que la referencia primordial de Dioselina fue la familia materna y las mujeres. La transmisión de conocimientos y valores del padre y la madre a hijos e hijas se interpreta como una labor vertical, taxativa y rígida. Lo curioso de este aspecto es que más adelante, cuando como investigadores nos adentramos a los espacios de reivindicación étnica desde la recuperación de prácticas medicinales y espirituales, el discurso de la transmisión de la memoria se torna amoroso y las figuras de los abuelos y padres (espirituales y ancestrales) se relacionan con el cariño, el cuidado y la protección. Las figuras de los ancestros devienen en cariñosas y cálidas, en contraste con el respeto autoritario de los mismos padres.

Un primer aspecto que se resalta en el relato de Cecilia frente al tema es que la niñez significaba algo distinto a concepciones metropolitanas contemporáneas, pues ser niña representaba trabajar, más en ambientes rurales. A las imágenes del paisaje se le suman aquellas de las responsabilidades y las anécdotas referentes al quebrantamiento del orden establecido por la familia y el trabajo.

En mi niñez mi papá se iba todos los días a las cinco la mañana al ordeño porque él era el que administraba la hacienda. A las siete de la mañana alguno de los cinco hijos nos mandaban a llevar el desayuno, nos íbamos y eso era como caminar de aquí a San Bernardino, digamos. Eso eran fincas ganaderas. Y ya le dábamos el desayuno a mi papá y nos daba una cantina de leche y 
nos teníamos que devolver como a las ocho de la mañana. Y en el camino había varias casitas de los mismos arrendatarios, entonces nosotros nos poníamos a veces a jugar con ellos y a veces se nos hacía tarde. Una vez me acuerdo que nos pusimos a jugar y un chino llegó y "pum", le pegó una patada a la cantina y me regó la leche. Entonces decíamos: "y ahora qué". Pero como por las orillas eran los vallados, entonces la completamos con agua, pa rendir la leche. Claro, y cuando llegamos allá mi mamá, como habían varios barrios y la gente venía por leche, entonces cuando llegaron: “¿qué pasó con esa leche?” Que eso era pura agua (Cecilia Chiguasuque, comunicación personal, agosto 18 de 2015).

La imposición del castigo también deja ver cómo eran las relaciones de género en la familia de Cecilia. Notaremos dos elementos: en primer lugar, que el castigo físico era más común para hombres que para mujeres y, en segundo lugar, que las transmisiones de intercambio energético por acción entre los roles de castigadores y castigados y/o protectores y protegidos marcaban la calidad de las relaciones entre padre-madre-hijos-hijas.

Mi papá no tanto, pero mi mamá era muy estricta. Para (los) hombres había unos castigos muy severos, por ejemplo en mi caso, mi papá los colgaba a la viga y les daban garrote, mojaban primero el lazo, eso vertía sangre. Entonces yo veía eso pero no nos podíamos meter porque nos castigaban. A nosotras nos ponían era a la cocina y ponernos a moler. Y cocine y lave. Nos tocaba ir a los vallados a lavar, poner una piedra al lado del agua y ponernos a lavar. Le pegaban a uno por todos. Entonces uno se antojaba por ejemplo de un pedacito de chocolate o un pedacito de panela y vaya uno a ver el castigo, sobre todo a los hombres. Eran muy estrictos y ahora cuando como en ese tiempo tomaban mucho, se venían pa'l pueblo y llegaban borrachos, y eso se peleaba con mi mamá, nos pegaba, nos sacaba en la cama y nos daban a veces por nada. $\mathrm{Y}$ eso era en toda la comunidad yo pasaba por una casa y ahí tenían a los chinos amarrados y las mujeres allá trabajando en 
la cocina y haciendo todos esos oficios. Por eso era que uno respetaba mucho, porque uno sabía qué castigo le generaba.

Yo una vez cuando éramos más grandecitas, cuando yo volví de Cali, mi hermana ya tenía un novio y se veían todos los domingos en misa. Entonces un día me dijo: "camine que vamos encontrarnos con Raúl”. Y nos encontramos ahí cerquita y ellos se pusieron a hablar y hablar y cuando me di cuenta ya eran como las cuatro de la tarde y le dije: "camine vamos a la casa que no hemos hecho almuerzo, ahorita llega mi papá y nos tienden a juete”. Y corra, y como tocaba hasta que prendiera el fuego y todo eso, cuando me mandé a una zanja, entonces él ahí sí corrió a sacarme. Porque mi papá a mí sí nunca me castigo, nunca supe qué fue una palmada de él. Él me quería mucho a mí, yo era la consentida de él y pa todo era yo. Yo la iba mucho con él, me consentía mucho, nos sentábamos a hablar, me contaba historias, era como la consentida de él. En cambio mi mamá sí no. Todo lo malo era yo, era la que más me pegaba, la que más me ponía trabajar y Delfina era la consentida. Ahí sí había como esa diferencia, digo yo, cada uno de los hijos, a unos lo querían y a otros no.

De por sí yo fui como muy rebelde, demasiado rebelde porque tenía el apoyo de mi papá, y yo casi de cocina poco, en cambio mis hermanas si eran allá clavadas en la cocina. Yo me le rebelaba a mi mamá y me iba por allá a los vallados (Cecilia Chiguasuque, comunicación personal, agosto 18 de 2015).

De la cita extensa anterior, también vale la pena resaltar dos aspectos: en primer lugar, que el castigo es visto por Cecilia como transmisión del valor del respeto, el cual no solo se da ante los padres, sino ante el orden que toca guardar cotidianamente, por esa razón causas como la comida o la recreación fácilmente podían terminar en un quebrantamiento de las reglas. En segundo lugar, la división por géneros del castigo: violento para hombres y particular para mujeres. Esto último se refiere a que las labores que socialmente se les otorgaban podían ser intensificadas para volverse castigo severo: lavar la ropa, ir a la cocina, traer patos, etc. 
En el marco de los recuerdos en torno al castigo y la autoridad de los padres surgió una imagen-recuerdo interesante por varias razones: el río. En primer lugar, porque al ser un elemento del paisaje que denota pureza y sanidad territorial, es usado como referente para contrastar el pasado de la vida "sana" de antes a la "insana" de ahora. En segundo lugar, porque oscila entre ser un espacio relacionado con la recreación infantil y un elemento castigador. En tercer lugar, porque el castigo enmarcado en el río hace ver a dicha acción correctiva no solo como la operación violenta sobre el cuerpo, en este caso seguramente denotada por el frío y la rudeza del caudal, sino como “purificadora”, como si el castigo de los padres connotara curación y limpieza.

Que sí nos da pesar ver cómo contaminaron el río cuando uno disfrutó ese río, cuando uno tomó esa agua, lavaba, se bañaba, porque a nosotros, mi mamá nos botaba en la mitad del río para que nos bañáramos. Ese era el castigo de acá, porque era muy raro que le pegaran a uno, pero el castigo, la sentencia era eso. Mi mamá nos decía: vamos al río a bañarnos, y uno decía: ¡ay! Qué hicimos ahora y mi mamá cargaba como una correíta y allá nos botaba, nos dejaba un ratico y nos sacaba. Y decía: no vuelvan a hacer males porque las castigo y uno ya casi ahogado dentro de ese río. Eso era bonito (Inés Neuta, comentario personal, julio 18 de 2015).

\section{Usos, costumbres y cuerpo de valores comunitarios}

Los recuerdos de sus roles como hijas y nietas comienzan a yuxtaponerse con imágenes bucólicas y de vida de pueblo pequeño. Un primer aspecto que resaltamos de este conjunto de usos y costumbres corresponde a la relación entre el calendario agrícola y las prácticas de cultivo. Lo importante de esta es que brinda referentes de los que ambas conarradoras definen como una identificación con el mundo "campesino"; más adelante, sus narrativas configurarán la indigenidad al re-significar tales prácticas. 
Mi papá para sembrar miraba la luna, claro, miraba todo eso [...] Había otro mito en la siembra, mi papá hoyaba, con varios hombres habrían los huecos y las mujeres sembraban. Mi mamá cargaba las semillas aquí en un costadito. Yo me acuerdo que doblaba así el delantal y las metía ahí y a nosotras nos decía que le ayudáramos a meter las semillas y me decía: 'eche de a dos o tres', y yo le decía: 'porque si se muere una la otra vive'. Mi papá iba con los hombres abriendo huecos para sembrar. Las mujeres éramos la que sembrábamos y la gente era muy trabajadora. Mi mamá sembraba, ella trabajaba, ella cortaba el maíz, de todo (Dioselina Triviño, comunicación personal, septiembre 15 de 2015).

El autoritarismo de la figura del padre, incluso hacia la esposa, es contrastado con otro elemento de la relación entre lo masculino y femenino que emerge en las narrativas de estas mujeres. Es cuando de la subyugación se pasa a narrar la "complementariedad" y entonces aparece el rol de la mujer como "portadora de semilla" y del hombre como "depositante", claramente relacionado con la sexualidad, la fertilidad y la abundancia. La constelación de imágenes femeninas se complementará con el manejo del calendario lunar, el cual no solo permitió a sus ancestros el manejo del tiempo cotidiano, sino además saber el sexo de un bebé por nacer. De esta manera se configura la constelación semilla-luna-maternidad-adivinación como características femeninas en el mundo campesino-muisca que comienza a ser interpretado a partir de las imágenes-hábitos.

Cuando ellos me decían 'apúrese mija que se le hace tarde pa' la escuela', miraba la guía del sol, la telita que teníamos en la casita. Me decía: 'mija, son las doce'. Cuando había una muchacha embarazada, decía: 'va a ser un hombre' o 'va a ser una mujer', porque en creciente nacen las niñas y en menguante nacen los hombres. Ellos usaban el Bristol antes. En ese tiempo no había reloj ni nada (Dioselina Triviño, comunicación personal, septiembre 15 de 2015). 
Cecilia aporta recuerdos similares en relación con el manejo de los astros y el tiempo. Incluso le permite calificar moralmente a sus ancestros como personas de pensamiento recto y claro, moral derivada de tal manejo del tiempo.

Por eso fue que cuando ellos empezaron a decir que los caminos de luna, nosotros no entendíamos eso, porque mi papá no tenía reloj ni nada de eso y decía: 'es la una, son las cuatro' y era exacto. Que eran las tres de la mañana cuando cantaba el gallo, y exacta. No necesitaban de relojes pero su pensamiento era muy exacto (Cecilia Chiguasuque, comunicación personal, agosto 18 de 2015).

En la medida en que avanzan los recuerdos de usos y costumbres, la siembra y la cosecha logran evidenciar la imagen de comunidades colaboradoras, solidarias y de estrechas relaciones vecinales. Alrededor de la comida se estrechaban lazos comunitarios y se forjaban relaciones intrafamiliares e interfamiliares, las cuales se recuerdan como perdurables a largo plazo. Por supuesto, la hospitalidad y la familiaridad siempre iban acompañadas de una abundancia en comida que las sustentaba.

También, nosotros, o yo me acuerdo, cuando mis abuelos, nosotros íbamos a la casa de mis abuelos, y los fogones eran en el centro de la cocina y así como estamos, todos, la familia llegábamos y teníamos así, como unas bancas para sentarnos alrededor de la cocina y el fogón en la mitad con las ollas de la comida, eso era bonito, porque todos nos arrumábamos a la cocina, así estuviera llena de humo, pero todos éramos felices. Así como dice doña Cecilia, había mucha comida en ese entonces, en los potreros abundaban comida, muchas veces hasta se dejaba las cosechas a no recoger, porque no se alcanzaba a recoger, a nosotros nos consta [...] Era que antiguamente, Bosa, era una ciudad de abundancia de comida, porque había cosechas, sobretodo de arveja, de frijol y de haba, que no la cogían porque no la alcanzaban a recoger, eso lo dejaba en los potreros, no se sabía si era porque no había venta o no 
alcanzábamos a recoger lo que se sacaba, eso era muy bonito (Inés Neuta, comunicación personal, julio 28 de 2015).

Y el Sábado Santo era que se sembraba, no importaba si llegaba en marzo o abril, casi siempre han sido esos dos meses, pero toda la comunidad salía a sembrar porque el terreno ya estaba listo y se hacían los convites. Había mucha comida. Se echaba todo eso a una olla y se calentaba a toda la comunidad y chicha, eso sí. Nos conocíamos por apellidos y porque eran los mismos. Y como se repartía comida para la comunidad entonces nos llegaban platados, esa mesa era llena de platos, y los que preparábamos también los repartíamos (Cecilia Chiguasuque, comunicación personal, agosto 18 de 2015).

De manera similar, Dioselina Triviño e Inés Cecilia Neuta resaltan tales relaciones vecinales, pero resalta además que se estrechaban relaciones colaborativas en ámbito laboral, además de un elemento esencial para el campesino sabanero de antaño: la tierra era de las familias, aunque no habían fronteras marcadas de manera rígida. La apertura de los límites entre las tierras se correlacionaba con el grado percibido de confianza y simpatía entre vecinos.

En tiempos pasados, Don Albertino, Don Pedro, con mi tía, ellos bajaban a ayudarle y en ese tiempo no ponían obreros. En ese tiempo se ayudaban unos con otros y se echaban su chichazo, tomaban su chicha, cultivaban, todos eran muy unidos. Cuando había siembra se quedaban, entonces cuando cultivaban se recogía y se le daba a los otros [...] La medida de la tierra era por cabuya y colocaban un lindero una piedra o un palito, pero eso lo medían con cabuya. Es decir, digamos que había una tapita o algo así y decían: 'de este lado para allá es de los Yopasá y de este lado para acá es de nosotros'. Después fue que empezaron a tirar alambre. Todo era solo a pie, después ya que de pronto en burro, entonces cuando los vecinos o los paisanos prestaban el burro, entonces iba en burro o caballo y mi papá se dedicaba a todo lo que eran cultivos (Dioselina Triviño, comunicación personal, septiembre 15 de 2015). 
En las horas de la comida, que todos íbamos al potrero a trabajar, había una persona que se quedaba en casa a cocinar. Ya cuando estaba el alimento, llevaban las ollas hacia el potrero porque, pues, toda la gente trabajando, no veníamos a casa sino hasta la noche. Y todos llegaban, ponían la olla en la mitad y todos sentados, alrededor, se usaban unas tazas, pero unas tazas así de grandes, y nos daban la sopa que hoy comimos, pero eran unas tazadas muy ricas de todo lo que se estaba cosechando (Inés Neuta, comunicación personal, julio 28 de 2015).

A la relación calendario agrícola-siembra-luna se le suma la Semana Santa, no solo por marcar la temporada de siembra del año, sino porque las celebraciones religiosas se tornaban escenarios de convivencia, fortalecimiento de relaciones y puntos de referencia muy importantes para marcar ciertas diferencias en las rutinas de la vida cotidiana. Por ejemplo, Dioselina llega incluso a usar el día santo, el domingo, como referencia para marcar las diferencias notorias del vestuario campesino de Suba.

Muy católicos, más que todo mi papá, los Triviño son mucho más católicos que los Bulla porque mi papá pasaba las oraciones nocturnas, pero en ese tiempo ya tenía diez o doce años, estaba en la iglesia desde el viernes y hacía culto hasta el domingo. Uno antes no se preocupaba por el vestuario, yo me acuerde de mis cotizas, que íbamos los domingos a salir al pueblo. Las elegantes eran las de fique, las cotizas eran para dominguiar (Dioselina Triviño, comunicación personal, septiembre 15 de 2015).

En el caso de Cecilia, la Semana Santa marcaba dos diferencias en la rutina diaria: el cambio de alimentación, marcado por la abundancia y ciertas licencias que solo se permitían en esa época del año, así como la validación de la autoridad paterna (tema tratado en un apartado anterior) mediante el rígido respeto hacia Dios, materializado en tabúes y prohibiciones. Estos últimos establecen relaciones sociales entre días de la semana y comidas específicas. 
Por ejemplo en las semanas santas se hacía mucha comida, porque nosotros lo que más consumíamos era la mazamorra, se hacía de desayuno, almuerzo y comida. Lo que sobraba era otra vez al desayuno y así otra vez la rutina. En nuestra casa había un día especial que mi papá nos dejaba comer algo que llamábamos sequito, que no es sopa, y eso era el día jueves, para nosotros eso era una dicha porque toda la semana comiendo sopa, entonces ellos tenían la costumbre de que ese día se podía hacer seco, entonces se hacía pasta, lenteja, fríjol, todo eso, para nosotros era una dicha que llegara el jueves. Papá nos mandaba comprar una gaseosa y ellos se tomaban de a dos cabritos. Y mi mamá desde temprano, y eso eran muy, muy creyentes porque ella antes de la Semana Santa le ponía a uno a alistar el agua, arreglar la casa, limpiarla, todo eso y desde el lunes hasta el sábado nosotros no podíamos hacer nada. Ni siquiera nos dejaban toser, porque "donde ustedes tosan”, nos decía papá, “le están tosiendo a Jesús”. Y mi papá se había comprado un radiecito y nos ponía a escuchar el sermón de las siete palabras, y ahí todos sentados y no podíamos nada. Y era solo comer porque pa esa semana Santa sí había mucha comida (Cecilia Chiguasuque, comunicación personal, agosto 18 de 2015).

Los ejercicios de asociación que Cecilia y Dioselina elaboran las llevan a vincular la comida con las celebraciones religiosas y a estas con las fiestas familiares y vecinales. Sin embargo, al analizar con cierta profundidad, un elemento no solo se repetirá en sus testimonios, sino que nos da pistas sobre los cambios de vida de los campesinos descendientes de pueblos indígenas durante el siglo XX. Dichos cambios están relacionados con el fortalecimiento de su rol como mano de obra capitalista y población consumidora de ciertos bienes y servicios, política promovida por el Estado de la época. Revisemos en primera medida lo relatado por Dioselina:

La tomada siempre era de guarapo y de chicha, la chicha cuando había festividades y el guarapo para los trabajadores. En esos tiempos cuando trabajaban era unos zurrones. Eso a uno lo alimentaban 
con la chicha, en el tetero a uno le daban. Empezaron a conocer el Cabro, luego la Alemana, después la Andina y la Costeñita (Dioselina Triviño, comunicación personal, septiembre 15 de 2015).

El cambio que nombrábamos es el de la chicha, bebida tradicional de origen precolombino, a la cerveza, introducida por empresarios alemanes. Cecilia, al igual que Dioselina, reitera las marcas de cerveza de la época como referentes y puntos de memoria:

Había fiestas. Había fiesta en San José y había fiesta en San Bernardino. Y habían las quermés, hoy día les llamamos bazar. Todas las fiestas, el 6 de agosto, el 20 de julio, y eso se hacía fiesta. Entonces ahí eran los encuentros, mi mamá por ejemplo era la que siempre sacaba toldo para la comida, la comida de ella era muy apetecida. Le gustaba mucho hacer huesos de marrano, hacer esa pelanga que llaman, hacer la mazamorra chiquita, hacer la chicha. La chicha se hacía por ejemplo cuando se casaba una persona o cuando había un bautismo, todo eso. Había una señora que se llamaba Elvita que tenía un barril grandísimo y entonces cuando se hacía una actividad tenía uno que ir como dos meses antes para que le prestara ese barril, y ese barril recorría toda la comunidad. En ese barril era que se hacía chicha pero se compartía todo el tiempo. Luego entró la cerveza, porque la primera que llegó aquí a Bosa se llamaba Cabro. Y era dulcecita pero también emborrachaba (Cecilia Chiguasuque, comunicación personal, agosto 18 de 2015).

Con los cambios vienen las resistencias. Ante la prohibición del consumo de chicha, las familias la escondían para beberla en secreto. La continuación del relato de Cecilia no brinda información sobre el rol de la chicha como elemento de la identidad cultural. Sin embargo, tal como lo expusimos para el caso de la luna, la chicha es considerada por Cecilia como un elemento tradicional y cotidiano que más adelante va a ser re-significado y simbolizado en el marco del rescate de repertorios de tipo espiritual. 
La chicha la prohibían porque cuando empezó a llegar la cerveza a Bosa ya llegaban los guardias que llamábamos, la misma policía, entonces se dijo que la chicha se acabó porque llegó Bavaria a expender todo eso, entonces ya empezaron de casa en casa y si llegaban y encontraban chicha entonces nos la regaban, varias veces, nos la regaban. Pero entonces nosotros éramos más astutos. Como a mi papá si le gustaba harto la chicha, en el centro de la casa abrió un hueco grandote y puso un moyo grande y lo enterraba. Ahí hacíamos la chicha. Entonces todos los días hacíamos la chicha y entonces cuando alguien decía "llegó la guardia", íbamos y traíamos una plasta de pasto y la colocábamos ahí y ya. Y así lo hacíamos mucha (gente de la) comunidad. (No era de mujer) no sabíamos el sentido que tenía la chicha. Nosotros la hacíamos porque era como nuestra bebida, más que todo de los mayores y para las fiestas, pero nosotros no sabíamos ni lo del maíz porque nunca supimos de eso (Cecilia Chiguasuque, comunicación personal, agosto 18 de 2015).

Por supuesto, un hallazgo importante respecto a la chicha es la transmisión de su preparación, sus clasificaciones y sus usos, datos de los cuales Cecilia representa una transmisora de memoria por excelencia:

Había tres formas de chicha. Era una fuerte que era pa los mayores, otra que era más suave para los jóvenes y otra que era para los niños. Para los mayores eso duraban como 15 días haciéndola las mayoras, porque en ese tiempo la chicha era muy diferente como se hacía. Yo me alcanzo a acordar de que el maíz lo molían en piedra y duraban varias abuelas y arrodilladas con la piedra, y muela, y muela. Primero lo partían, después lo echaban en unas canecas grandotas, lo dejaban ahí unos dos o tres días hasta que fermentaba, después lo iban repasando y eran días haciéndolo. Y también escogían las mejores mazorcas, porque salían unas mazorcas, una belleza. La desgranaban, la ponían al sol para que se secara bien, luego la partían y luego la metían en canecas a dos o tres días con agua y la dejaban ahí y ya... Pero después de los dos 
o tres días llegaban y los sacaban y eso tenían unas mochilas, eso que hacen de costales, y las amarraban en cada moyo o múcura le metían unas cuatro libras, pero primero la cogían con un trapito o una mantica y luego la metían en el costal, y la amarraban bien y por allá las metían unos dos o tres días y las enterraban. Enterrada duraba 15 días esa masa. Cuando salía ya había nacido semilla y estaba toda nacida, y eso era el fermento, lo que nacía del mismo maíz y era cuando empezaban, claro, y eso era una cosa muy fuerte. Y eso duraban noche y día cocinando (Cecilia Chiguasuque, comunicación personal, septiembre 5 de 2015).

$\mathrm{Al}$ indagar en las memorias de usos y costumbres vamos encontrando dos elementos: el primero, que las rutinas y prácticas alrededor de la comida, la siembra, el calendario agrícola, las celebraciones, las redes familiares y vecinales y la chicha suelen hacer parte del contenido de los recuerdos de las mujeres muiscas de Bogotá en su niñez campesina, elementos que más tarde van a ocupar un lugar relevante como parte de los ejercicios de memoria en sus comunidades. A esos elementos campesinos se les va a otorgar la identificación como usos y costumbres indígenas muiscas. El segundo, estos elementos que podríamos denominar como característicos de una vida bucólica y romántica son resaltados como "de antaño" y, por tanto, su desaparición o necesidad de recuperación significan o indican la afectación que los avances de la modernidad y de la urbanización implicaron en las comunidades descendientes del pueblo muisca. La chicha evidencia el paso de la bebida casera a la industrial y del campesino al consumidor de clase obrera y popular de los municipios aledaños a la capital. En los siguientes apartados, otros indicadores de los cambios de vida serán analizados.

\section{Leyendas y desmitificación: transformaciones en el territorio, alteridades y reflejos}

Cuando se habla de memoria indígena y campesina, el campo de la narrativa mítica y de leyendas emerge como un escenario obligado. Cuando 
Cecilia y Dioselina relatan respecto a este punto, tres registros se presentan: el primero corresponde al mito y leyenda como narración transmitida, a modo de memoria de sus ancestros depositada en ellas, como espacio de comunicación familiar. El segundo al mito y leyenda en calidad de acontecimiento del que se fue o no testigo, como una experiencia de diferente naturaleza con el mundo de los espíritus y las energías del territorio. Y el tercero a manera de elemento pedagógico y de transmisión de valores. Como ya es sabido, los personajes de las leyendas basan su accionar en violaciones al orden moral y social. En el caso de lo registrado en esta investigación, a medida que se desmitifican las leyendas, el territorio ancestral es intervenido con más agresividad y los impactos en la vida cotidiana de Dioselina y Cecilia son de mayor envergadura.

Ambas registran como receptoras de historias transmitidas: a ambas les contaron leyendas de sus territorios de origen. La diferencia está en la manera en la cual desmitifican los acontecimientos en sus narraciones. Cecilia resaltó durante las entrevistas que siempre fue rebelde. Pese a que actualmente es considerada una abuela con conocimientos espirituales por parte de personas de su comunidad, no niega crecer como incrédula de las historias de espantos que le acompañaron:

Se daban muchas leyendas, muchos mitos. Por ejemplo nos comentaban de la Sombrerona. De la Sombrerona decían porque el hombre era borracho y se lo llevaba, que en Semana Santa se abría el cerro de Osatama o de Tierra Negra, de allá salía oro y no sé qué, eso era un misterio. De las comadres, las candilejas habían salido porque se habían unido dos compadres y que se habían condenado. Ahora la otra que mató el hijo, entonces nos contaban era historias. Por ejemplo aquí abajo, bajando por una parte que llamábamos Molinos, y nosotros por no dar esa vuelta nos metíamos por una zanja y ahí decían que había un misterio, que ahí salía un perro negro y que eso asustaba, pero yo nunca vi eso. Había otra parte cerca donde era la finca de nosotros que era un señor que se había ahorcado y decía la gente que cuando pasaban después de la medianoche lo veían rajando leña en medio del fuego. Pero yo nunca vi eso. Como yo caminaba aparte, 
yo no creía mucho en eso (Cecilia Chiguasuque, comunicación personal, agosto 18 de 2015).

Para Dioselina, en cambio, el asunto no es la incredulidad. La desaparición de ciertos fenómenos sobrenaturales obedece al desencanto del territorio, fruto de la intervención de la modernidad. De esta manera, con el avance de la vida moderna en Suba, lo que ocurrió no fue que se comprobó que nunca hubo espantos ni espíritus en los territorios; no significa que la racionalidad moderna dejó atrás las supersticiones antiguas. Con la modernidad los encantos desaparecieron por causas materiales y del orden metafísico traído por ella misma. En su relato el elemento territorial más relevante es el agua.

Nosotros nos criamos con agua por todo lado, todo puro y el agua era de los bosques. Mi papá en la casa de donde vivimos hizo un aljibe, en la casa de mi hermana María. Mi papi vio que había un nacimiento de agua y con piedras lo arregló, entonces mi mamá nos decía: 'Suba es muy rico, todo eso de la Conejera, todo eso, hay una mina de oro', y le dije: ‘¿quién le contó eso mamá?' y me dijo: 'pues los abuelos', que había una cadena de oro en todo eso. Agarra todo lo que tiene que ver con la Conejera hasta llegar a los altos de San Jorge. Yo era muy pequeña cuando caminábamos hasta el Quirigua a llevar cosas. Mi mamá me decía: 'mija, arregle los canastos', y yo salía a arreglar los canasticos y caminábamos desde la laguna hasta el Quirigua y eso eran árboles, pasábamos toda una arboleda para llegar al Quirigua. No le decían tanto el Quirigua sino los Cerezos. En la laguna veíamos peces y cangrejos, porque uno antes caminaba por el agua y se veía en el agua, uno caminaba por el pasto y se le hundían los pies hasta por acá y se veían los pescaditos. Desde el Rincón hasta los Cerezos había también una calle de herradura y nada de pavimento ni nada. Me decían que en esa laguna salía la Candileja, era una mujer que era toda de candela y que tipo 11 de la noche, 12 de la noche, la veían, mi abuelo me decía que la veía. El encanto se perdió porque la tierra la acabaron, esto antiguamente la llamaban Aguas 
Calientes y dicen que esto era como los termales de Suba, las familias se iban para allá a bañarse que la tierra duró dos años y que se mandó la tierra, que del fondo de la tierra salía humo porque se acabó el encanto (Dioselina Triviño, comunicación personal, septiembre 15 de 2015).

Como es habitual en los relatos campesinos, los espíritus y espantos se comunican con los humanos vivos mediante tesoros y guacas. Lo interesante no es solo que en el mundo moderno los entierros indican las huellas del pasado que pueden afectar materialmente a cualquier persona. También que en la modernidad misma el pasado se espiritualiza y, con este, los referentes de la identidad indígena se revelan en la metamemoria. En los relatos de las mujeres se comienza a hacer evidente que la identidad indígena no hizo parte de sus generaciones ni de las de sus padres, pero sí de los más antiguos. Hoy día sabemos que también hace parte de los más jóvenes, con lo cual queda claro que la identidad indígena muisca sí está ligada a la memoria de las familias pero en horizontes temporales de largo aliento, avanzando hacia ese pasado no testificado pero recibido generación tras generación, como hacia el presente-futuro de los que han indigenizado a sus recientes ancestros campesinos.

Inés nos compartió tres relatos. En todos, además de narrar la forma en que las guacas se presentan a los humanos, también explica la relación moral entre ambos. La guaca solo se le presenta a quien desea y desaparece cuando tal relación no es correspondida y mantenida de tal manera unívoca.

Pues nosotros hablamos, de lo que mi abuela nos contaba, que aquí, los papás de mis abuelos eran indígenas, indígenas, lo que era el puro indio de que se morían y le echaban la chicha, los envueltos, collares, de todo lo que hubiera, porque ellos se iban según al otro mundo, e iban en un viaje muy largo e iban a aguantar hambre por allá, esa era la creencia acá, eso nos contaba mi abuela. 
Ellos alcanzaron a ver esos entierros y ella nos mostraba en qué sitio los enterraban.

Aquí en Bosa, como hubo mucho indígena, se usaba mucho el oro y la plata, y donde enterraron los caciques, ahí había guacas, porque hay mucha plata acá en Bosa. Lo hablo yo, porque yo me casé y las guacas no se les presentan a los que creen o de pronto las conocen. Se presentan a personas que no conocen ni saben qué es. Una vez, acá tuvimos una costumbre que en la muerte de algún familiar. Pasó una ocasión, que hicieron una misa de mi abuelo. Entonces dijeron, "Bueno vamos para la casa porque allá hay qué comer" Entonces dijeron "Sí, vamos". Todos nos fuimos para la casa. Pero como no alcanzamos a llegar a la casa, porque les gustaba tomar, se quedaron en el camino tomando, como de ahí para abajo quedaban muchas tiendas de cerveza, entonces nos sentamos a la orilla de una zanja, que llamamos nosotros, desagües, se usaban para pegar las cementeras. Estábamos todos sentados, toda la familia. Esa vez nos habíamos reunido, aproximadamente, 30 personas y estábamos todos así, tomando y charlando. Estaba mi esposo, que él no era de acá, entonces, él estaba sentado en la orilla de la quebrada que corría el agua. Entonces, estábamos todos en charla y ríanos, y estaba haciendo un solazón (solazo). Entonces él, estábamos sentados a la orilla de la quebrada y por allá en la orilla había una mata que se llama "Saus", al pie de la quebradita, y él estaba molestando con un palo. Entonces le dije yo: Estate quieto que usted se va a ir allá de pie, porque estaba casi ya con los pies en el agua y se lava porque eso es hondo. Y él se puso a jugar con el palo por ahí, cuando él vio, de la raíz del palo, le salió un montón de billetes, pero que era un montón, según él decía. Era un montón de billetes que salían y brotaban encima; el agua estaba ya turbia, pero en ese momento se aclaró el agua. Y él decía: Yo vi el montón de billetes en el fondo, pero como él no sabía que por esos sectores había mucha plata y oro enterrados, a él se le presentó eso, entonces él lo que hizo, estaba un cuñado de mi mamá, él lo que le hizo fue “¡ay! Mire, Luis, Luis, allá hay plata”. El otro lo alcanzó a ver, pero a lo que él se fue a cogerla, la plata 
se desapareció, la plata se fue. Entonces, todos le decían, "pero la riqueza era para él”, no para el otro, sino para quien la había visto. Y él después me decía: ¿Y eso qué es? Le dije: Pues plata que hay enterrada debajo de ese árbol y se le presentaba a usted. Usted le avisó al otro, no era para él, entonces la plata se corrió, se fue. Y eso escarbaron, corrieron a la casa, trajeron azadones, trajeron ganchos, escarbe ¡Ya qué! Como decía mi tía, pero para qué escarban si la guaca era para él, no para usted, para qué van a escarbar allá, y eso duraron jumm casi toda la tarde escarbando para que saliera la plata. Mi marido decía: Uy, pero eso era artos billetes, porque él vio fue billetes, y decía mi tía, ¿pero usted para que fue a decir? Eso era para usted que lo hubiera cogido. Como él decía, yo no conozco eso, yo no he visto eso. Por eso, damos razón que en esos sectores hay plata, hay oro enterrado, porque los indígenas antiguos se enterraban con la riqueza, que eso era la vida de qué de los indígenas (Inés Neuta, comunicación personal, julio 18 de 2015).

A Nancy, hace como 10 o 15 años, a ella se le presentó la guaca en una gallina, y le pegaba a la gallina con los pies y ella no le hizo nada, pero disque una gallina hermosa. Antiguamente, salían muy tarde de la casa, en la noche, para darle vuelta al ganado, porque había ocasiones que gente mala se robaba el ganado, entonces, los que tenían ganado, tenían que levantarse a dar vueltas en la noche, y ella se levantó a ver el ganado y cuando ella salió a la cocina, la gallina se revolcaba entre la tierra pero ella no le hizo nada. Ella fue y llamó a la mamá y la mamá le dijo: ¡Ay! Pero si eso no era para nosotros, era para usted, pero ella no la cogió, mejor dicho no la tocó, porque la guaca, según decían mis abuelos, la guaca al que se le presente toca golpearla o tocarla para que ese espíritu se quede quieto, pero ella no lo hizo. Ya después, se corrió de ahí, porque no volvió a salir. Eso es lo que damos fe nosotros de cómo era aquí Bosa (Inés Neuta, comunicación personal, julio 18 de 2015).

Entonces eso era muy bonito cuando mi abuelita nos contaba todas esas historias, es como lo de los cerros de Cerro Gordo, mi 
abuelita también nos contaba y mi papá, Cerro Gordo en Semana Santa, el Viernes Santo, ellos miraban a las 3 de la tarde el cerro y el cerro se abría y salía un hombre dorado allá en el cerro pero a las tres de la tarde el que quisiera ver el hombre dorado se paraba y miraba hacia el cerro y el cerro se veía hermoso porque ese cerro, según decía mi abuela y todos, que ese cerro tenía mucho oro o tiene mucho oro todavía (Nancy Neuta, comunicación personal, julio 18 de 2015).

Las imágenes-hábitos pertenecientes a la dimensión mágica del territorio alimentan la imagen positiva de los elementos materiales y culturales de la vida comunitaria y familiar del pasado campesino-muisca. Pese a ello, no siempre los referentes de lo mágico y misterioso fueron considerados como rasgos positivos por los campesinos-muiscas. En ese orden de ideas, el siguiente hallazgo es particular. En primer lugar, porque reitera el rol de trabajadoras de las mujeres campesinas de Bogotá y el rol autoritario y de sus padres con tendencia al castigo. Pero en segundo lugar, por lo que proponemos denominar como "alteridad" y "reflejo". Nos referimos a que mujeres que hoy día se diferencian del resto de la sociedad en tanto muiscas, antaño se consideraban parte de la sociedad general y mimetizadas performativamente en los sectores considerados mayoritarios socialmente. Por esa razón, desde un punto de vista étnico, no se consideraban diferentes de los campesinos y del resto de la sociedad colombiana. La "alteridad", los "otros" eran otros, entre ellos la etnia romaní o gitana. Lo interesante es que décadas después, las mujeres muiscas sí van a buscar diferenciarse étnicamente, tal como lo percibieron de las gitanas. Incluso, en el relato de Cecilia las gitanas le mostrarían cierto exotismo y misterio de una alteridad considerada con atributos mágicos y peligrosos, algo que más adelante ella narrará respecto a la forma como la juzgaron por comenzar a trabajar medicinalmente con plantas y el tabaco en su propia comunidad. A eso llamamos "reflejo". El siguiente fragmento mostrará rasgos tanto de la alteridad como del reflejo depositado y permitido por sus recuerdos sobre las gitanas en Bosa. 
Es que esa finca era un criadero de patos, pero muchos patos, entonces existían y todavía existen las gitanas. Las gitanas iban en ese tiempo a donde mi mamá, entonces ellas bajaban por ahí cada mes a comprar la pluma. Y había tres clases de plumas. La primera era la fina, la segunda era la medio fina y la tercera la rústica. La primera era para hacer almohadas, la segunda era para hacer colchones y con las otras alcanzaban (a) hacer fonjas rellenas. Entonces muchas veces el castigo era ir a recoger esos patos allá en los vallados, pero eso era recoger harto, a veces nos daba la noche trayendo todos esos patos. Ese era el castigo de ella a veces cuando lograba que me cogiera. Me trasnochaba, lloviendo, descalza y todo eso a traer los patos, porque al otro día tenía que matarlos porque llegaban las gitanas. Nosotros le teníamos temor a esas gitanas, porque me contaba que donde yo no hiciera caso de traer los patos, las gitanas nos robaban y nos mataban. Porque se vestían de esa forma, y como nosotros nos vestíamos digamos, pues lo normal, pero es que ellas usaban unos trajes muy hermosos y con túnicas, y con collares, esos vestidos, esos zapatos, iban en esos severos caballotes (caballones), con esos caballos adornados en oro y todo eso, entonces parecía que uno fuera historia, eso qué televisión ni qué radio ni que nada, era lo que veíamos del día a día. Campesinos, nosotros siempre fuimos campesinos, nosotros nos criamos como campesinos y eso nos hacía creer mi mamá. Y nosotros para ir y traer esos patos pues nos íbamos y veíamos desde bien arriba llegar a esas gitanas y nosotras las que se pierden. Nosotras no nos quedábamos en la casa, nosotras nos íbamos vallado abajo. Yo les tenía un terror pero terrible. Y todavía siento yo, así cuando me saludan, en los encuentros que ha habido, siempre hay recelo porque me llega ese pensamiento, pero ellas nunca nos hicieron nada. Ellas nos llevaban pan, nos llevaban colombinas, pero yo nunca con ellas (Cecilia Chiguasuque, comunicación personal, agosto 18 de 2015).

"Yo nunca con ellas", afirma contundentemente Cecilia. En cambio, sus narraciones retoman quiénes eran verdaderamente los suyos, 
y para ello resalta la forma en que las familias se relacionaban no solo para convivir sino para conformar una comunidad emocional que se vivía reproduciendo socialmente desde mucho tiempo atrás y esperaba seguirlo haciendo.

\section{Cortejos, matrimonio y endogamia}

Consecuente al recuerdo de una vida comunitaria y vecinal marcada por las mismas familias y los mismos campesinos, la endogamia marcó una característica en aquellos grupos descendientes de muiscas en Suba y Bosa. Los apellidos reiterativos en las generaciones venideras serían tomados como unos de los elementos más importantes para el reconocimiento de una comunidad indígena en Bogotá. La endogamia marcaba las relaciones estrechas entre familias por generaciones y entre territorios veredales. En la primera parte de su relato respecto a estos temas, Cecilia aplica nuevamente una fórmula nemotécnica y narrativa que ya vimos anteriormente: tomar como referencia los itinerarios de vida de un ancestro, en este caso los de su esposo.

Es que a uno le gustaba su muchacho y ya con el tiempo se casaba. Pero no había más. Uno llegaba acá al pueblo y eran los mismos con los mismos. Entonces uno se conocía con los mismos. Yo conocí a mi esposo en una fiesta en San José. Él era de aquí pero se crio en Soacha, mi suegro era el que tenía una finca donde hoy es la casa. El abuelo se lo había dejado a él. Mi suegra era de Ramiriquí. Porque aquí existió lo que llamaban las revolvedoras de chicha, porque Bosa era una de las partes donde la gente venía a comprar la chicha. Aquí en la esquina estaba la casa de los Escobar e iba mucha gente a tomar chicha. Entonces me contaba mi suegra que se vinieron 10 muchachas de Ramiriquí, mi suegra ya tenía una niña, Olga María, y entonces llegaron aquí a Bosa y se pusieron a trabajar ahí como revolvedoras de chicha. Y todas se quedaron con un muisca, digamos, porque todas, ahorita no existe ninguna. Pero mi suegro vivió todo el tiempo con su abuelo en Soacha. El no conoció ni papá mi mamá (Cecilia Chiguasuque, comunicación personal, agosto 18 de 2015). 
Luego va a caracterizar las fases del cortejo y casamiento: frivolidad en fiestas, encuentros informales, encuentros formales, pedida de mano y matrimonio. Todo regulado por la autoridad de los padres y enmarcado en las formas propias campesinas de celebración y hospitalidad que ya hemos presentado anteriormente.

Conocí a mi marido en una fiesta donde se casó una prima. Mi marido se llamaba José Gabriel Tarquino, él es Tarquino Ruíz. Ahí eso era curioso porque una resultaba quitándole el novio de la otra, porque en ese tiempo cuando fui a esa fiesta él estaba de novio con otra prima mía y yo también molestaba con un muchacho que era de El Porvenir. Pero al comienzo no le puse mucho cuidado ni nada de eso. Pero fuimos saliendo y como eso era fiesta tras fiesta, la comunidad tomaba mucho. Ya tenía uno después de cierto tiempo, ellos tenían que ir a pedir permiso a la casa y ya uno no se encontraba por ahí en la calle sino que ya era la casa, llegaban era a la casa. Eso era como cuando uno se iba a casar, los papás de él y él, tenían que llegar temprano a las cinco de la mañana a hacer el pedimento de mano. Y siempre tenían que llegar con una botella de aguardiente. Con tres hermanas pasó lo mismo, porque nosotras tres salimos casadas de la casa. Eso no, qué sala, era ahí en la cocina. Por lo general, la fiesta era en la casa de la novia, por eso para las tres la fiesta fue en mi casa. Más que todo llegaban como a acordar el matrimonio. Y eso era de tres días la fiesta porque eso había mucha cerveza, mucha chicha, mucha comida y eso era toda la familia la que se invitaba y duraban días ahí tomando, y las fiestas eran muy bonitas porque todo mundo se invitaba, nunca se encontraban problemas (Cecilia Chiguasuque, comunicación personal, agosto 18 de 2015).

A partir de los bloques temáticos anteriores en los que hemos organizado los relatos de vida de las mujeres muiscas parece sacarse una conclusión típica: "todo tiempo pasado fue mejor", en términos morales, ambientales y emocionales. Las narrativas, sin embargo, deben tener puntos de giro, coyunturas. 


\section{La llegada de la vida moderna}

En las narrativas de Dioselina y Cecilia se notan las transformaciones geográficas como puntos de giro de sus historias, tal como se espera de cualquier relato. En la experiencia etnográfica, sin embargo, las diferencias entre ellas marcan otros dos registros. Mientras Dioselina privilegia el territorio y las costumbres de los ancestros como los objetos de afectación, Cecilia se privilegia a sí misma. Dioselina elabora parte de la narrativa de los cambios sufridos mediante dos coyunturas: la primera está conformada por la transformación de los materiales de construcción de sus casas, lo que a su vez se relaciona con la llegada de la explotación minera a Suba:

En ese tiempo ya mi mamá se enamoró con papá y ya empezaron a ver en Suba, porque ya empezaron a ver la alfarería, fuera del cultivo de maíz, de su chichita, de su guarapo, empezó a haber la alfarería. Era que cavaban barro, hacían teja, ladrillo. Yo hice teja e hice ladrillo. Moliniaban con el caballito y sacaban teja, o sea que mi padres trabajaron en eso cuando llegó Juan para las casas de bahareque y después trabajaron en barro. Para las casas normales de ahora elaboraron el ladrillo y la teja, entonces mi papá aprendió a hacer teja y ladrillo. Se volvió minero, allá donde Hernando Rojas, un señor que llegó a Suba porque los Rojas no son de Suba. Eso de una vez les pedía los predios y formaban los techos y les daban en arriendo chicha. Lo que yo veo en la cultura era gente muy confiada, como muy que confiaba mucho (Dioselina Triviño, comunicación personal, septiembre 15 de 2015).

Las narraciones no solo narran, también ordenan moralmente el mundo. Por esa razón Dioselina emplea como segunda coyuntura a la chicha y la vincula con ciertos apellidos y actos de abuso de confianza. Dicha sanción moral por lo general tiene causa en la explotación y usurpación de tierras, motivo que más adelante tomaremos como los pilares que dieron origen a las organizaciones indígenas contemporáneas en Suba y Bosa. La explotación de arenas precedió al intento 
de la petrolera en Suba. Dioselina, a manera de un leitmotiv, vuelve y aprovecha el relato para dar a conocer su orden moral y su forma de interpretar la mistificación del territorio y sus fuerzas con el irrespeto al orden de la naturaleza.

Suba estaba rodeado de agua, era poco el terreno para los cultivos. Para hacer la Boyacá fue que eso lo secaron y rellenaron. Y rellenaron esas lomas, todo eso era por donde llevaban las ovejitas. Nosotros tuvimos un terreno ahí al pie de las antenas de Tv Cable. Todo eso era supuestamente de nosotros, es que ya ahoritica nos organizamos como cabildo. Todo, todo era resguardo, ahora con la averiguación y todo. Mi mamá lo que si decía era que antiguamente el gobierno no había dado mucho. No era una tierra para todos, cada cual era dueño de un pedazo, pero no era tierra comunal. Toda la familia de mi mamá era dueña de esa cantidad de terreno y arriba también nos dejaron. Lo que pasa es que antiguamente, como Suba era tan llena de agua, por lo que había mucho humedal y agua, en época de lluvia se inundaba. Entonces también les dejaban arriba para que fueran y dejaran el ganado en tiempo de lluvia. Abajo era de siembra y en tiempo de lluvia era eso: subir a los animales para que no se ahogaran, por eso es que papá y mamá tenían terreno en lo plano y terreno en lo alto. Nosotros somos dueños de un pedazo grande que supuestamente vinieron a cavar hace muchos años, a cavar petróleo. Creo que sacaron e hicieron firmar a mis hermanas y a mi mamá pero dicen que jamás fueron a la notaría a firmar. Fue luego que unos vecinos, unos paisanos, dijeron: 'tienen que vender o vender y hay que cederle el terreno a esa gente porque vienen a sacar petróleo’. Entonces comenzaron a cavar, a abrir, entonces empezaron las dragas y empezaron a traer todo para romper el cerro y ellos que abrían de día y de noche se les tapaba (Dioselina Triviño, comunicación personal, septiembre 15 de 2015).

En cambio para Cecilia, la llegada de la vida urbana es narrada en un registro más personalizado. El siguiente fragmento da cuenta 
de la división social del trabajo que era deparado para los campesinos e indígenas en el siglo XX. En primera medida, el trabajo como empleada de servicio de la familia del hacendado patrón de su padre le fue esquivo: "yo fui la única que no me pude acomodar en esas casas. Cuando yo me fui tenía 12 años. Mis hermanas si duraron toda la vida trabajando en esas casas hasta cuando se organizaron, cuando ya consiguieron sus compañeros y se organizaron" (Cecilia Chiguasuque, comunicación personal, agosto 18 de 2015).

El espíritu rebelde de Cecilia la llevó a tomar la decisión de intentar una vida mejor en la ciudad de Cali. Cuando la servidumbre no resultó ser su destino, casi lo es la prostitución, un trabajo que se volvió normal para migrantes campesinas en grandes ciudades:

Pero yo sí solo trabajé como tres años y en ese tiempo conseguí una amiga de esas que están trabajando ahí, ella era de Cali, y entonces me dijo: "camine y nos vamos pa Cali". Yo de una vez arranqué con ella y duré tres años viviendo allá. Sino que ella me llevó allá a otras cosas que yo no quería, por allá que algunas casas de prostitución y yo lo que hice fue irme. Yo me quede en un parque y había como un CAI, entonces los policías se dieron cuenta y me dijeron: "mija, y usted qué hace ahí, vea que es peligroso". Entonces me dijeron que me quedara en el puesto de policía. Entonces me llevaron pa llá, yo amanecí con ellos y uno de los policías me dijo que tenía la esposa y dos hijos y si quería irme a trabajar esa casa, y en esa casa libre casi los tres años. Cuidaba a los niños, hacía de todo ahí (Cecilia Chiguasuque, comunicación personal, agosto 18 de 2015).

\section{Primera salida: la mujer como tejedora de memoria}

A manera de sumario, hemos clasificado hasta ahora los relatos de Cecilia, Inés y Dioselina en siete bloques que corresponden a su vez a lo que proponemos denominar "constelaciones", es decir cadenas y redes de objetos, prácticas e ideas que se conjugan en ciertos escenarios y eventos que son resaltados en las memorias de las mujeres 
muiscas consultadas y transmitidos como imágenes-recuerdos e imágenes-hábitos: linaje, historias de ancestros, autoritarismo paterno, usos y costumbres, mitos y leyendas, transformaciones de la vida en los territorios, historias de alteridades y matrimonios endogámicos. Tales bloques nos han permitido identificar los primeros roles de la mujer muisca en procesos de recuperación de la memoria indígena de Bogotá.

Como resultado inicial, nada novedoso por ahora, la mujer cumple el rol de transmisora del linaje, no solo por generar la vida para que las familias se sigan reproduciendo, sino además porque suelen ser receptoras activas de las historias y anécdotas de sus ancestros. Tienen la competencia de elaborar grandes mapas generacionales a partir de los itinerarios de sus padres, abuelos y de otros mayores. Su rol se intensifica cuando la "casa" se convierte en un referente fundamental para elaborar los recuerdos y narraciones, además de ser las transmisoras de las historias escuchadas. La memoria se torna netamente femenina y enmarca el recuerdo, como lo vimos en la introducción del presente libro, en la vida doméstica y cotidiana. Cumplen el rol de reproducir los órdenes morales, de ahí que resalten el autoritarismo de sus padres, los castigos relacionados tanto con lo físico y el trabajo, como por su división de género: los trabajos femeninos de la cocina, el aseo y la crianza son determinantes y llegan incluso a reforzar el rol femenino en la familia mediante el castigo, de ahí que cocinar, alistar los alimentos o buscar patos se confundieran como trabajos cotidianos y castigos a las mujeres.

En su rol de recordadoras y transmisoras, cumplen el rol tradicional de la reproducción social de la comunidad. Transmiten a las generaciones nuevas los usos y costumbres de antaño, si no para volverlos a poner en práctica, por lo menos para brindarles un significado profundo como elementos indígenas en lo contemporáneo: la siembra, el manejo del calendario agrícola, el uso de las fases de la luna, el manejo del tiempo a partir de la luz del sol, hacer llover, festejar, preparar ciertos alimentos, la chicha y fortalecer tejidos comunitarios entre vecinos a partir de todo ello.

También son receptoras o testigos de la mistificación de las fuerzas territoriales y naturales: saben los mitos y leyendas, contados por sus mayores y a veces los niegan o los relacionan con procesos de 
afectación territorial y transformación de usos del suelo. En sus memorias está contenido el cambio del campo a territorios urbanos, de cultivos a minería. Cuando no transmiten los recuerdos del territorio lo hacen de sus propias vidas, de sus propios cuerpos, por eso las migraciones y las labores relacionadas con la división social de trabajo hacen parte de sus historias.

Van a transmitir encuentros con otros extraños, para luego volverse esos extraños, como en el caso del reflejo otorgado por las gitanas con sus majestuosos vestidos y los rumores de sus poderes mágicos. Y finalmente cumplen el rol tradicional de la hija, de la novia, esposa y madre, una secuencia que suele marcar el itinerario de vida de la mujer muisca, lo que enmarca su rol en la memoria en estrecha relación con la de reproducción social.

Los resultados de nuestra investigación cobran sentido por medio del contraste y del tránsito. Cuando de una vida plagada de recuerdos bucólicos y que aparentemente nada tenía que ver con la vida indígena, las mujeres pasan a narrar la manera en que se convirtieron en sujetos étnicos; en la forma como tomaron elementos de su pasado campesino para activar discursiva y activamente su indigenidad en el marco de coyunturas históricas que dieron origen a la organización comunitaria indígena en Bosa y Suba. A continuación, los bloques temáticos integran la narrativa femenina de cómo las mujeres colaboradoras se reconocieron a sí mismas como mujeres indígenas muiscas.

\section{Segundo horizonte: la coyuntura de la organización y el presente de la mujer muisca}

La finalidad de elaborar historias de vida de estas mujeres muiscas era tanto comprender las formas de construir su indigenidad, así como identificar sus posiciones de sujeto. Esto último se refiere a una postura en la cual se afirma que la pertenencia a cierto grupo social no implica homogéneamente que todos sus miembros tengan las mismas posiciones frente a temas como la distribución de la riqueza, asuntos 
de género, medio ambiente, etc. En ese orden de ideas, nuestras conarradoras si bien van a coincidir en sus visiones e interpretaciones frente a ciertos aspectos que rescatan de sus memorias como contribuciones relevantes a los procesos de identidad comunitaria, tendrán distanciamientos en la manera en que asumen roles de participación en la organización indígena local, pues esta marcará diferencias en asumir sus posiciones frente al rol de la mujer indígena.

Particularmente, el punto de giro que marca las diferencias en las posiciones de sujeto es el comienzo de la organización indígena que fundamenta el restablecimiento del cabildo indígena en Bosa y Suba.

\section{La indigenidad fue alimentada desde afuera}

A partir de las narraciones anteriores, las mujeres nos permiten interpretar sus roles en la memoria de sus comunidades como de mujeres que fueron testigos de usos y costumbres de antaño y de los cambios que sufrieron sus territorios y las vidas de sus habitantes. Sus recuerdos se tornan enseñanzas para las generaciones de jóvenes - hoy adultos- que van a liderar la recomposición del Pueblo Muisca de Bacatá desde sus aspectos culturales, políticos y espirituales.

Cecilia Chiguasuque aplica una fórmula narrativa que es constante en Bosa cuando se relata el proceso de organización indígena por cualquiera de sus miembros fundadores: la categoría identitaria "indígena" no era asumida por nadie, llegó como un constructo aportado por personas externas y colaboradoras, en este caso por profesionales que desde sus consejos y asesorías recomendaron asumir la indigenidad para lograr resultados más eficientes por parte del Estado ante la comunidad doliente de varios procesos de expansión urbana hacia el sur de la ciudad.

Nosotros nos creíamos campesinos y luego fue cuando llegaron y empezaron a decir que existían los chibchas, ni sabíamos qué era eso. Decíamos: “¿Chibchas qué es?”. Para saber que nosotros éramos una comunidad fue que como esos terrenos eran de todos, nadie tenía escritura, entonces un señor de los Cobos contrataron 
(contrató) a un ingeniero y dijo que necesitaban arreglar esos terrenos, que le entregaran sus escrituras. Entonces ese señor llegó ahí a la comunidad y empezó a hablarnos de los indígenas, porque él sí sabía que en Bosa si habían indígenas. Entonces él empezó hablar de eso y empezó con tres familias. Con la familia que lo había contratado y con otras más que se unieron, y entre esas estaba una prima hermana mía, entonces ella empezó a llamarnos: "vengan que este señor va a decirnos que somos indígenas, que nosotros tenemos beneficios y que no sé qué". Eso fue como en el 90. Una vez hicieron una fiesta en una casa de esas y eso hubo chicha pa todo mundo y de las fincas regalaron una vaca. Y eso hubo comida pa todo mundo. Entonces en ese encuentro hubo como 10 familias, pero es que en nuestra comunidad las familias son muy numerosas (Cecilia Chiguasuque, comunicación personal, agosto 18 de 2015).

El caso de Suba fue similar en dos aspectos: en primer lugar, porque la motivación para la organización fue la recuperación de tierras que habían sido arrebatadas a las familias de antaño con fines de expansión urbana. En segundo lugar, porque la indigenidad fue alimentada por factores externos. En este caso, un miembro de la comunidad, fruto de los contactos de los descendientes de muiscas con la ciudad y sus dinámicas fue quien trajo elementos del conocimiento moderno-occidental, como la normatividad y el derecho para liderar la organización. Dioselina narra en extenso esto y se integra al relato como una persona a la que su rutina profesional fue interrumpida abruptamente por este acontecimiento.

Resulta que nosotros estábamos en la casa normalitamente y todavía teníamos una parte de siembra en la casa. Yo trabajaba porque pues tenía la vida normalita; estudié en el colegio y fui empleada de la clínica Shaio por varios años. Yo trabajé 30 años, me pensioné en la clínica Shaio. Entré como auxiliar de la dentista, yo entré como de 18 años y después empecé a estudiar poco a poco. Después entré a trabajar en laboratorios y estudié auxiliar 
de enfermería, estudié en un instituto y después de eso me pasaron a laboratorios. En el laboratorio clínico trabajé 17 años y todo el tiempo trabajé en esterilización y salí pensionada.

Resulta que estando yo trabajando llegó mamá y dijo: 'mija, a usted la están buscando, que va a haber una reunión y que hay un señor que es de acá de Suba que está haciendo unas averiguaciones sobre los territorios, como han venido evolucionando todos estos terrenos entonces que va a haber una reunión, que hay que ir mija'. Porque mi mamá toda la vida, le quitaron el terreno arriba y ella quedó con que 'nuestro terreno nos lo quitaron', ella fue la que me entusiasmó de ir a la reunión.

Doña Inés Guerrero era la dueña del colegio, yo fui y le pregunté que si don Carlos Caita, que Carlos Arturo Caita, supuestamente era Caita de los de ahí, que era el que iba a montar la reunión. Ese día la verdad fuimos unas 24 personas, entonces mi madre me mandó, pensando en su terreno. Ese día el señor dijo que había estado averiguando y que resultaba que en Suba habían quitado muchos predios, las familias, los grandes, porque lo que entendimos de tiempos pasados, para disolver eso, porque venían familias de otros lados que cogían el terreno y decían 'présteme esta partecita y yo cultivo en compañía'. Entonces nuestros paisanos a sus padres les daban, nosotros no hicimos eso porque poco terreno tenía mi papá, pero gente que tenía más terrenos hábiles pedían el terreno para sembrar en compañía. Entonces qué pasaba, que ellos les daban más chicha, llegaban hasta embrutecerlos y les hacían firmar y les hacían quitar así la tierra, entonces llegaron los Rodríguez. Incluso con los animales llegaban a pastear y en unos lotes pequeños metían los animales y cuando usted se daba cuenta ya eran tenedores de tierras. Entonces mi mamá con todo eso que había vivido y la familia que había peleado tuvo la intención de que fuéramos a esa reunión a escuchar entonces al señor Carlos Caita. Creo que ya se había puesto a mirar el Archivo Nacional y todo eso.

Según lo que había entendido es que el tipo trabajaba con el Agustín Codazzi y el tipo se dio cuenta lo que Suba había sido. A 
partir de eso el tipo ya hizo sus investigaciones y él lo que quería era reunir a las familias para reorganizar y poner el sistema organizativo no como cabildo, ellos no lo habían pensado como cabildo, revivir la estructura organizativa de la comunidad que existe en este momento. Entonces ya empezó a llamar y a convocar la gente. La primera reunión se hizo un sábado como a la una en el liceo Teflor. Fuimos las 24 personas y el señor empezó a explicar todo. Mis hermanas y mis sobrinos de la misma familia fuimos con un poquito de desconfianza, porque ya nos habían quitado tierras y pues que también de pronto nos quedáramos sin nuestra parcelita, entonces siempre como nerviosos y el señor nos tenía reunidos con las personas y comenzó a decirnos que nuestras familias y uno empieza a acordarse. Somos nativos nada más y cuando él explicó todo, que la verdad era que habían terrenos baldíos, que llegaban otros y se apropiaban y que empezáramos cada uno a cuidar nuestros terrenos. Que para eso teníamos que armar una junta para que fuéramos a reunirnos por tarde cada 15 días o mes por tarde, para comenzar a hacer la averiguación, que él ya había averiguado. Incluso él traía una escritura del Archivo Nacional y el señor se dio a conocer e hicimos las averiguaciones y sí, él era de Suba y la familia de él toda de Suba (Dioselina Triviño, comunicación personal, septiembre 15 de 2015).

Los procesos organizativos, motivados por asuntos de tierras, hicieron que la aceptación de la identidad indígena por parte de las comunidades de Bosa y Suba fuera un rito transicional, de cierta manera, que no fue fácil de asumir en un inicio, pues los elementos discursivos traídos desde afuera tendrían que ser asimilados en la dimensión personal e íntima de nuestras narradoras.

\section{Asumir la identidad indígena}

Para personas como Cecilia, asumir la identidad indígena no fue fácil. Irónicamente, ante un proceso de recomposición étnica ávido de fuentes de memoria que fundamentaran tal identidad, lo que había era un 
grupo de ancianos, memorias vivas, que no se reconocían como indígenas y llegaron incluso a reaccionar con burla y sarcasmo.

Después que le conté lo de las dos familias, entonces fue cuando ya nos hicieron ese convite. Entonces mi prima decía que aquí había una comunidad y yo le preguntaba: “¿y esa vaina que es?”. "Pues camine que el domingo va haber una actividad y allá se van a enterar"... Y pues ese día fuimos y el señor comenzó a decirnos que éramos indígenas, que éramos muiscas y todo mundo: “¿qué quiere decir muisca?" Porque no sabíamos qué era eso. Inclusive muchos mayores se burlaban de nosotros. Todavía hay mayores que me ven y dicen: "quiubo muisca”, o "quiubo indígena”. $\mathrm{Al}$ comienzo me daba como pena, hoy en día me siento feliz de que me digan indígena.

Me fui convenciendo porque ya entré al proceso, yo empecé a ir y como ya estaba Delfina, ya estaba Reinel, entonces ya me empezaron a invitar a las reuniones y yo sentí como que me gustaba estar ahí. Empecé a ir a las reuniones, empecé a enterarme, empezamos a salir a conocer otros pueblos porque ni conocíamos. Incluso mi apellido, yo sufría mucho por mi apellido porque uno iba al centro y no lo podían pronunciar. Chi chi chi.. chiva... chigua... y tocaba era escribírselo porque no lo entendían. Nos preguntaban que de dónde éramos, luego entendí que somos de aquí, nunca nos hemos ido, mis padres nacieron, se criaron y murieron acá, mis abuelos lo mismo. Porque por ejemplo por parte de mi mamá todos son de San José y mi papá sí era allí de San Bernardino y ellos nunca se fueron de aquí (Cecilia Chiguasuque, comunicación personal, agosto 18 de 2015).

Ante las dudas generadas por los mismos ancianos de Bosa, Cecilia comenzó a comprender elementos de su recuerdos que antes no había asumido como parte de sus herencia indígena, ejemplo claro el hecho de que las familias nunca habían salido del territorio de Bosa y, consecuentemente, el mantenimiento de sus apellidos. Una vez Cecilia 
ahonda en esos temas, en retrospectiva revisa su transición y algunas dificultades de este, sobre todo en lo que atañe a la aceptación de la indigenidad de sus coterráneos.

Nosotros no nos reconocíamos, no le digo que para nosotros éramos campesinos. Y chibchas, porque esa era la palabra. Ya decían que nosotros éramos como un pueblo y no se nombraba la palabra indígena, chibcha porque veníamos de tribus, lo decía la gente que ya empezó a llegar. Entonces nos decían que éramos los chibchas.

Yo no me burlaba, me daba como pena. ¿ No le digo que el señor que vino a arreglar lo de los terrenos dijo que nosotros éramos una comunidad? Habían abuelos, y aún todavía haya abuelos que se burlan, pasa uno y dicen: "adiós indígena, adiós indígena”. Y le digo yo: "iqué! Si usted es más indígena que nosotros".

Pues ahí mi familia casi no acepta eso. Yo fui la que, de toda la casa, de seis hermanos, yo fui la que comenzó con el proceso. Y logré meter a una hermana, pero hoy no está muy involucrada en eso (Cecilia Chiguasuque, comunicación personal, septiembre 5 de 2015).

En el caso de Suba, Dioselina en su narración deja ver cuestiones similares. Las familias se convirtieron en el núcleo de los procesos de reconocimiento étnico, acompañados de los respectivos obstáculos por parte de las instituciones que oficialmente lo legitiman así como los procesos intracomunitarios de auto-identificación indígena. El ejemplo más emblemático se dio con su madre, pues mientras en la naciente organización se comenzaban a identificar sus miembros como indígenas, ella se negaba rotundamente a aceptarlo y proponía, más bien, autorreconocerse como "nativa" y campesina. La palabra "indígena" se consolidaba aún más cuando hacía parte del discurso de las instituciones estatales que comenzaba a ser parte de los procesos de lucha de la naciente organización en Suba.

Tanto Cecilia como Dioselina comenzaron a encontrar en sus recuerdos y memorias familiares conexiones de las costumbres muiscas 
y de sus eventos históricos que los victimizaron como pueblo a medida que los procesos organizativos avanzaban. La conexión de las estructuras históricas con la vida familiar se va a convertir en un aspecto clave de la recuperación de memoria indígena, pues va a permitir que desde la vida cotidiana se elaboren procesos individuales y comunitarios de anclaje con la gran narrativa de la historia del Pueblo Muisca.

\section{Conexiones históricas con la vida familiar}

En la narrativa de Dioselina Triviño de Suba es donde mejor encontramos una manera de relacionar procesos históricos con memorias de familia. En su caso particular, la Guerra de los Mil días se convertía en un referente para entender que sus ancestros eran indígenas reclutados que habían sido recompensados por el Estado con tierras tituladas, aunque mediante procesos engañosos que luego forjarían el pilar de la lucha por tierras en Suba.

La escritura 1033 dice que el resguardo se disolvió en 1898, que es la fecha en la que se disolvió, pero digamos que dieron los papeles pero no se disolvió porque en la revisión que hemos hecho hay gente que no tiene papeles. Por lo menos imagínese que la parte de Tuna Alta, donde nosotros hicimos la reunión, están llegando avalúos catastrales a nombre de los antiguos, de los que ya están muertos, de los que son bisabuelos de los que ahora están vivos. En nuestra escritura dice: 'entregado al indígena Juan Bulla', fue en 1888. Mi mamá nació en 1910.

¿Sabe cuál fue ahí el problema? Que hubo mucha gente digamos, porque mi mamá era muy juiciosa de tener los papeles al día, porque mi papá era, o sea, muisca que se respete, eso de la chicha. Esa era la historia que no solamente contaba mi mamá, sino que he escuchado a varios mayores que decían que tenían que esconder en las hornillas de las casas las escrituras para que ellos no vendieran las tierras, y para que no las cambiaran por cabezas de ganado ni chicha y yo creo que mi mamá fue una guerrera en ese sentido, porque siempre estuvo como cuidando y protegiendo la 
tierra. Porque era para proteger, para sus hijos, la cultura que tenían era: 'yo no puedo dejar a mi hijo en la calle, a mí me dieron mis padres, yo tengo que dejarle a mis hijos, parados así sea en dos pastos de tierra donde puedan estar tranquilos, donde puedan cavar una mata de maíz, una de papa, una mata de fríjol'. Porque ellos tenían de dónde comer, por eso era que ellos no aguantaban hambre, porque no se hacía nada más que echarle leña al fogón y coger la comida, porque yo me acuerdo que yo cogía para la sopa para hacer nuestra comida.

En Suba varias familias, los hijos de los hijos, ya empezaron a... sumercé sabe que los más viejitos trabajaban y les fascinaba cavar la tierra, ararla, arreglarla y empiezan a morirse los viejitos. Ya los que quedan son un poquito flojos, entonces la gente ve que ya no cultiva, que ya no hay nada, comenzaron a vender los pedacitos de tierra, a doce mil pesos el pedacito de tierra y así la gente como avarienta y pues... (Dioselina Triviño, comunicación personal, septiembre 15 de 2015).

Al igual que lo ocurrido con Cecilia en Bosa, Dioselina comenzó a asumir su identidad como indígena y para ello tuvo que confrontar a varios agentes externos e internos que contribuyen mediante su discurso a negarlos o a reafirmarlos como grupo cultural y social.

Ahí me gustó el proceso y cuando nosotros tuvimos la primera reunión ahí en la Alcaldía: 'no, que los indígenas de Suba'. Eso fue un bombo saber que éramos, porque las instituciones decían que no habían en Bogotá y se pararon a mirarnos a ver cómo éramos, y yo con la pinta normal y nos preguntaron: 'ustedes cómo sienten lo indígena, como sienten la cultura'. Nos tocó muy duro porque las instituciones nos trataron duro, fue duro. Eran despectivos porque en el pensamiento el indígena es el que anda con taparrabo, esa es la visión y la gente no tiene la culpa porque les enseñan que un indígena es con taparrabo y plumas. Entonces cuando lo miran a uno, lo miran con escepticismo porque no le ven los taparrabos. Tuve una vez que pelear en un escenario con una persona: 
¿Qué pena con usted! Yo soy muisca, yo soy de este territorio y así yo no use, ni mis ancestros usaron taparrabo, porque con ese frío tan verraco que hace acá, nos tocaba con mantas y con ruanas, con iquiras'. Y apenas quedó como... sí, es como decirle a un pasto, ande con taparrabo (Dioselina Triviño, comunicación personal, septiembre 15 de 2015).

Hasta acá podemos comenzar a entender qué posiciones de sujeto van asumiendo las narradoras en sus relatos. De sujetos-mujeres, con estilos de vida campesinos y de veredas que transitaron a barrios urbanos, asumieron ser sujetos étnicos, es decir, confrontar e incorporar una identidad indígena que antes no existía.

Su incipiente militancia en la organización comunitaria las hizo asumir una posición de ciudadanas ya que mediante la incorporación de una nueva identidad podrían defender el territorio como pilar fundamental de la herencia ancestral y la recomposición cultural de su pueblo. Esto acompañado con una posición política que estuvo de acuerdo con aprender y aplicar la normatividad estatal que permitiera la existencia de sus comunidades como diferentes a la occidental-mestiza. Por ahora, no sabemos si al ser sujetos étnicos, estas mujeres coinciden en sus posiciones como sujetos económicos o de género. Esto se profundizará en la medida que exploremos otro aspecto que resaltará en sus narrativas como un punto de giro relevante: su liderazgo comunitario.

\section{Liderazgos femeninos en la organización social indígena}

Cecilia Chiguasuque hizo parte de los miembros de familia que comenzaron con la organización indígena en Bosa en la década de los 90. Como es normal en las narrativas de mujeres indígenas, sus trayectorias de vida atraviesan un momento de militancia y participación política, materializada, por lo menos nominalmente, en asumir cargos del naciente cabildo indígena. 
Pero yo iba a las reuniones, eso participaba en todo, y fue cuando empezamos a formar las autoridades. En esa reunión que leyó, porque yo duré como 12 años de autoridad. Primero fue Oscar Melo, luego Virginia Chiguasuque y Edwina Tunjo. Cuando ya formamos las autoridades luego dentró Reinel, dentró Isabel, dentré yo, dentró Rigo. Yo siempre fui alguacil menor. Pues ahí, como le dijera, estar con la comunidad supervisando todo lo que se hacía, asistir a la reuniones y participar en todo lo que se trabaja en los pueblos, en las otras comunidades (Cecilia Chiguasuque, comunicación personal, septiembre 5 de 2015).

Dioselina profundiza más en este aspecto. Su participación el cabildo la hizo ver su memoria de manera diferente: comenzaron a liderar recorridos por el territorio para recuperar memorias ya asumidas como parte del legado indígena, recordaron fiestas religiosas, su amor por la tierra y demás elementos para poder consolidar el tránsito hacia una identidad más consolidada comunitariamente. Para también narrar cómo los antropólogos y las instituciones "validadoras" de la identidad étnica fueron fundamentales en la elaboración de una identidad nueva para familias de Suba.

Después de cuatro o cinco reuniones nos organizamos como cabildo con todas las de la ley, volviendo a reconocer nuestra cultura, las cosas que toda la vida las llevamos acá, que nos nacía. Caminábamos harto, todos los días salíamos a caminar, son cosas que empieza uno a recuperar, ese amor por las matas, por toda la naturaleza, entonces uno empieza ya la vivencia de qué rico, 'lástima mamá de no haber más tierra para sembrar'. Mi cabeza me empezó a dar muchas vueltas, porque mi mamá no dejaba un pedacito de tierra sin sembrar, una matica de maíz, una matica de esto y entonces ya fue cuando hablamos con Don Carlos. Las instituciones nos cerraban las puertas, nos tocó pensar en un terreno para todos. Por decir, nosotros estamos aquí y hace un tiempo yo 
veía entre casas sembrados de papa, más antes cuando era niña, que era cuando caminábamos, después eran siembras de trigo. Papá era el amigo de Gustavo Rodríguez, que supuestamente el señor apareció diciendo que era el dueño de todo eso y resultaron metiendo ganado, y el señor puso unos cuidanderos en esa finca, metieron ganado, un toro, y mi mamá no podía ir a arriba con los otros porque soltaban el toro y los sacan (sacaban) corriendo. Mi mamá comenzó a entristecerse por eso pero ahorita cuando nos volvimos a unir las familias comenzamos a pensar: ‘ $¡ H o m b r e !$ Nosotros tenemos nuestro resguardo'.

Nos hicieron la visita los antropólogos. Al Ministerio se pasa todo el listado del censo, nosotros hicimos un censo de casa a casa. Juntando escrituras, partidas de bautismo y de registro civil donde se vea que son del apellido y que en verdad están situados en Suba, y que vienen de ese tiempo, y vienen a mirar el historial de cada persona. Después de tener todo ese historial se llevó al Ministerio de fuero indígena. Cada nada nos citaban a fuero indígena y a la Alcaldía Mayor y empezaron a hacer un estudio antropológico. El Doctor Zárate fue el que fue a Suba y dijo: 'ustedes que son de acá, dirán cómo se reúnen las familias que se conocen, que supuestamente se conocen, entonces comencemos con todas las familias'. Entonces hablamos de los días de San Isidro, de los días con las familias. Nosotros nos conocemos todos en el Rincón, en la vereda o barrio Rincón. Los de allá de Tibabuyes se conocen todos, los del Salitre se conocen todas las familias y los que uno medio conoce por un pacto, uno los conoce o los tiene en cuenta. Ya entonces, en una de las reuniones que habíamos hecho, nos encontramos las mismas familias, eran las mismas caras y llegaban: 'mire, que el hijo de mi hija'. Entonces, cuando el señor nos dijo que teníamos la reunión con el antropólogo y llegaron tres señores y de la Alcaldía mandaron también un revisor y: ‘cómo se van a reunir ustedes?' Entonces don Pacho, reunimos la junta: ‘qué nos inventamos?’ Matamos una gallina en un asado y don Pacho, en un potrero grande, en una finca que tenía harto maíz por un lado, nos reunimos todas las familias. Eso fue grande la 
reunión, fue poner la olla y prepararon el asado. Unos prepararon la carne, otros la papa y ellos fueron y miraron toda la gente. Se sentaban en grupos: 'usted de qué familia es, cuánto hace que vive aquí en Suba, usted cómo sabe que es indígena'.

Pero pues como nosotros ya veníamos organizados, nosotros en las reuniones hacíamos los talleres, se habla de 'usted nació de dónde', también con el trabajo de los abuelos, ya nos sentábamos con los abuelos y con los más viejos a hacerles averiguaciones de: ‘cómo era el apellido, tío', y así. Entonces así cogían los grupos de familias y así fue todo el día. Eso fue desde la mañana porque eso arrancó desde las 8 de la mañana y hasta la noche, todo el día, y llegaron e hicieron el estudio etnográfico. También, hace más o menos 12 años, hicieron un estudio de cráneos. Para poder hacer eso nos tocó sacar de nuestro bolsillo, para pagar oficina" (Dioselina Triviño, comunicación personal, septiembre 15 de 2015).

A partir de estos puntos en las narraciones, vamos a encontrar que Cecilia y Dioselina asumirán diferentes posiciones de sujeto. Esto se da no porque no comparten algunos aspectos ideológicos del proceso indígena. Lo que ocurre es que mientras Dioselina se va a convertir en una transmisora fundamental de memorias de procesos de lucha por la tierra, el relato de Cecilia va a profundizar en otra dimensión que posteriormente va a alimentar los procesos de memoria muisca: la medicina y la espiritualidad.

\section{Sujetos políticos: lucha por la tierra y confrontación del poder masculino}

El Cerro la Conejera es un hito en Suba, no solo porque marca un punto de referencia en su territorio, sino porque es escenario de luchas permanentes por la tierra. Para los muiscas de Suba, varios de sus predios significan el abuso estatal y el peso de los intereses privados que llevaron al despojo de estos mediante engaños jurídicos. La recuperación por parte de la naciente organización indígena en Suba marcaría el comienzo de la lucha política en el marco de las identidades étnicas. En 
la medida que avanza su relato, queda claro que el liderazgo principal era masculino, representado en el primer gobernador del cabildo. Las mujeres conformaban un cuerpo de organización y lucha que halaba a sus familias para unirse a los procesos colectivos de organización y acciones populares como las tomas de terrenos.

Entonces el gobernador (Carlos Caita) hizo una reunión con la comunidad y dijo que se iban a tomar unos predios, porque Pedro Gómez va a construir apartamentos. Dijo que se iba a invadir esas tierras y que nosotros como indígenas teníamos que hacernos la toma y defender el territorio. Entonces organizaron un grupo de gente de acá del Rincón y pues se tomaron la Conejera donde están los apartamentos, los Altos de San Jorge. Eso era monte todavía y era tan bonito, porque uno iba y comía moras, yo alcancé a comer moras, esmeraldas, nosotros veíamos los conejos, animales, eso todavía había en esa época. Entonces nos fuimos y ese día nos llamaron porque teníamos que estar en familia, eso no era solamente el líder a la cabeza, sino que eran las familias, esposos y mujeres, todos fuimos allá. Ese día nosotros llegamos como a las seis de la mañana. Cuando llegamos ya estaba la policía ahí, porque el gobernador el día anterior había informado a la Alcaldía local de Suba que nos prestaran ayuda. La idea era que cada uno de nosotros lleváramos a armar cambuches y si nos tocaba quedarnos dos, tres días, ese tiempo teníamos que quedarnos en ese cambuche. Pero entonces la policía ya se preparó para no dejarnos montarla, no dejaron hacer cambuches ni nada, llegaron los antimotines, nos echaron gases lacrimógenos, todo venían, tanto de Suba como del Rincón. Ese día llamando al gobernador y no aparecía por ningún lado, puso a las familias a pelear pero no apareció y ahí fue que nosotros nos desilusionamos porque cómo fue a hacer eso. Después de la toma, Don Carlos había tenido que ir a Suba. Ya les habían pagado y habían mandado comida a la casa de la gente que había ido. A mí ese día me iban a llevar detenida pero cogí a todos y corra y eche pa' la casa (Dioselina Triviño, comunicación personal, septiembre 15 de 2015). 
Cuando se ponen en diálogo las narrativas de Cecilia y Dioselina un rasgo se vuelve habitual. Sin importar la reciente conciencia étnica tanto en Suba como en Bosa a finales del siglo XX, como narradoras rescatan como característica neta de las familias nativas su impulso de lucha con base en una identidad política radical. Cecilia no duda en conectar históricamente las luchas de la organización naciente en Bosa con el espíritu militante de la época del bipartidismo acérrimo que caracterizó al país durante gran parte del siglo pasado.

\begin{abstract}
Porque pues a los abuelos si les gustaba mucho la política. Mi suegro se hacía matar, pues era muy liberal y en Bosa habían conservadores. Mi suegro era terrible, mi suegro no podía ver a los conservadores, y él cada vez que iba al pueblo va borracho y se acordaba: "esa es la casa de tal conservador", y eso empezaba a decirles cosas, y a votarles piedra, a formarles el problema, y los señores que lo conocían llamaban a la policía y se lo llevaban, y eso le daban unas tundas, y cada vez que veíamos estaba en la cárcel porque no quería a los conservadores (Cecilia Chiguasuque, comunicación personal, septiembre 5 de 2015).
\end{abstract}

El ímpetu recordado en el espíritu de lucha de los ancestros parece conectarse con un ímpetu reivindicado en procesos más recientes. Además, las mujeres van a consolidar un liderazgo político como respuesta al poder masculino. Una vez Carlos Caita se consolida como gobernador del primer cabildo muisca de Suba, la administración del antiguo cementerio se va a convertir en uno de los logros más sobresalientes de su gestión y en un indicador claro de la legitimidad que la organización indígena había ganado en la localidad bogotana. Sin embargo, Dioselina no duda en calificar este logro como "el peor error para los indígenas”, pues las muestras de abundancia y prosperidad generaron dudas y desconfianzas frente al ético manejo financiero del cabildo. Finalmente, tales sospechas fueron el detonante de una revolución interna en la comunidad caracterizada por la reivindicación femenina. 
En ese momento empezó la administración, don Carlos administraba y hacían eventos de la comunidad: nos daban piquetes, chicha, carne y la pasábamos bueno en Diciembre. Entonces la comunidad empezó a preguntar de dónde Carlos estaba sacando, si era lo del cementerio, que hacer las cuentas y comenzó con que: 'yo soy el gobernador, yo veré como hago las cosas, por qué me van a pedir cuentas'. Eso fue un rollo allá y una pelea, y ese día fuimos y nos hicimos la toma al cabildo donde estaban nuestros documentos, nuestros censos y le dijimos que necesitábamos que nos entregara el cabildo y nos dijo que era el gobernador. Él duró como cinco años, desde el 91 hasta el 95. Entonces ya en el año 95 nos fuimos a hacer la toma de la oficina, porque ya le habíamos dicho en varias ocasiones que se iba a hacer elección de un nuevo gobernador y dijo: 'no, es que yo soy el cacique, eso no era así, yo sigo siendo el gobernador'. Claro, porque él si se había leído muy bien la historia del pueblo y él sabía que culturalmente el pueblo muisca no se manejaba como hoy se maneja, una organización de cabildo, porque eso ya venía de los cacicazgos y un proceso ya netamente cultural. Él decía que era autoridad suprema y que era el cacique y ¿quién organizó para hacer la toma? Pues nosotras, las mujeres. Ese día hubo puño, sacamos los papeles y ‘ $i$ este es nuestro cabildo!' (Dioselina Triviño, comunicación personal, septiembre 15 de 2015).

"Este es nuestro cabildo". Con dicha frase se consolida el proceso organizativo indígena en Suba, así como el autorreconocimiento étnico de sus primeros líderes e integrantes. De ahí en adelante, la vida de Dioselina comienza a trasegar en los cargos de autoridad que ejerció en el cabildo. Su liderazgo y ejemplo fue seguido por Myriam, su hija mayor, quien llegó a gobernar el cabildo por tres periodos consecutivos.

Como afirmamos líneas atrás, la indigenidad de Cecilia atravesó otros puntos de giro, pues más que un liderazgo político-administrativo, esta mayora de Bosa ingresó al mundo de la medicina indígena y consolidó su rol como "abuela sabedora" de su comunidad. 


\section{El camino de la medicina muisca}

Al igual que lo ocurrido con los procesos de la organización social y política, los liderazgos más relevantes en el naciente campo de la medicina y la espiritualidad muisca cayeron en figuras masculinas. Cecilia recuerda que fueron John Orobajo y Edward Arévalo Neuta, jóvenes de la comunidad de Bosa, quienes comenzaron a aprender de otros sabedores indígenas los conocimientos en medicina que marcaron la generación más reciente de especialistas. Curiosamente, y a diferencia del esquema narrativo que normalmente explica la transmisión de conocimientos "tradicionales" de los viejos a los jóvenes, Cecilia fue convocada e inspirada por John y Edward, quienes por edad podrían ser sus hijos. Este aspecto lo resaltamos, pues hace parte de un hallazgo significativo de la investigación: la indigenidad muisca se ha consolidado principalmente desde generaciones jóvenes, cuyos miembros, aunque han tomado los elementos culturales transmitidos por sus mayores, son quienes les han enseñado a sus abuelos y padres a aceptar y a asumir la identidad étnica.

Yo ahí empecé como por el proceso de medicina, porque una vez cuando empezó, cuando llegó un taita, John nos decía: “mire que va a empezar el proyecto con un abuelo que va a venir a enseñarnos medicina, nuestra medicina, miren a ver quiénes se inscriben”. En ese tiempo nos inscribimos como 10 personas, más de 10, eso fuimos como unas 15 , porque de las 15 terminamos como ocho. Nos enseñaron todo lo que el abuelo Orlando nos trajo, porque él mandaba a las de Carare. Nosotros todos los sábados éramos en un taller de ocho a una de la tarde y fue más de un año que nosotros estuvimos allí. Me gustó lo que empezaron a decir que significaba nuestro cuerpo, como teníamos que cuidarlo, porque me acuerdo que una Carare nos enseñó y nos colocó en un platico un huevo y nos dijo... Y ahí empezamos. Eso fue solo escribir prácticamente. Entonces ya empezamos las prácticas entre nosotros mismos, y ahí fuimos entrando (Cecilia Chiguasuque, comunicación personal, septiembre 5 de 2015). 
Reiteramos dos aspectos encontrados en los procesos de construcción de la indigenidad muisca: en primer lugar, fue alimentada por líderes foráneos a las comunidades, particularmente en lo que respecta a prácticas y rutinas ceremoniales y medicinales; en segundo lugar, son hombres quienes resaltan en la historia reciente de las comunidades muiscas como sus protagonistas. En el relato de Cecilia emerge la figura de Orlando Gaitán, quien después de haber trabajado durante muchos años como gestor de paz, se autorreconoce como indígena del Carare, se forma como chamán del yagé en Putumayo, establece una fundación para difundir su medicina y se consolida como un colaborador clave en los procesos de organización indígena en Bogotá y la sabana.

Cecilia recuerda que tal relación con Orlando se comenzó a vislumbrar como paternal, como la de un maestro que asume un rol protector y guía ante sus discípulos, a quienes les “enseña” y "va entregando" a medida que los ve preparados. En este caso particular, el proceso de reconocimiento étnico de Cecilia también estuvo marcado por el aprendizaje paulatino y progresivo de las plantas medicinales.

El tabaco fue lo último y es que el taita Orlando al colmo que nosotros estábamos allá, nos fue entregando, él fue el que nos fue entregando porque no se empezó a entregar primero lo del aprendizaje, como era lo de nuestro cuerpo, como era(n) las terapias, lo que había que curar, sanar, colocarle pensamiento bonito, bueno, todo eso fue solo enseñanzas. Y después ya él nos enseñaba cómo se curaba con el tabaco, como soplarlo y todo eso. Pero él al colmo que nosotros íbamos aprendiendo él nos iba entregando, para nosotros fue una entrega porque nosotros no podíamos ir a fumar un tabaco ahí sin saber para qué era. A mí me empezó a entregar todo lo que fue(ron) plantas, entonces todo lo que nos enseñaba decía: "esto es para esto..." Y yo ya sabía que es lo que me entregaba. A otra compañera le entregó fue unos totumos, a otra compañera le entregó los emplastes, y así entonces cada una cogíamos lo que el taita nos iba entregando (Cecilia Chiguasuque, comunicación personal, septiembre 5 de 2015). 
El relato de Cecilia cuando avanza nos da dos pistas interesantes sobre sus procesos de indigenidad. En primer lugar, cuando elabora la memoria de su aprendizaje en medicina indígena, Cecilia también reflexiona sobre su transformación personal. Asumió posiciones de sujeto frente a temas morales a medida que avanzaba en sus conocimientos. En segundo lugar, toma como imagen-recuerdo la construcción del cusmuy o "casa del agua", como se denomina el bohío sagrado que hoy se encuentra en el barrio San Bernardino de Bosa.

Yo a través de mi camino con John, que es el que me ha estado enseñando, entregando, y a lo último, hace como tres años me dediqué completamente a esto, porque yo, como le dijera, yo salía de esas terapias, salía a rumbear, a tomarme una que otra cerveza, a fregar y todo eso, yo no lo tomaba en serio, o no lo tomamos en serio porque ni el mismo John lo tomaba en serio, estábamos todos como hasta ahora aprendiendo. Entonces no, a nosotros nos parecía fácil estar en un taller de medicina, terminar e irnos por allá a rumbear, a tomarnos una cerveza, a fregar y al otro día ir a la reunión y así. Pero entonces cuando empezaron a dar más entrega, y más entrega, entonces yo le empezaba, a mí no me decían abuela, a mí me decían: "doña Ceci, vamos a estar en el cusmuy". Entonces yo ya ayudé a armar el cusmuy y no era porque me gustara sino como era autoridad entonces prácticamente como que me tocaba estar ahí (Cecilia Chiguasuque, Nemocón, septiembre 5 de 2015).

Desde el proceso de aprendizaje de la medicina, parece como si la indigenidad fuera directamente proporcional al uso de plantas medicinales y sagradas. Por esta razón Cecilia toma como imagen-recuerdo y referente la josca, tabaco en polvo, para narrar el “antes” y el “después” de la identidad indígena de los suyos y la propia. En la cadena nemotécnica vincula a Carlos Mamanché, otro sabedor de la medicina muisca, fundador de la comunidad de Sesquilé y quien también marcó un liderazgo fundamental en la historia reciente de las comunidades muiscas. Sin embargo, la "espiritualidad" que buscaban emanar y 
transmitir al resto de la comunidad fue opacada a veces por los estereotipos del drogadicto y el brujo.

Además, sus jóvenes maestros habían sido nombrados como líderes mediante la entrega del poporo y la coca o hayo, elementos hoy día característicos de los líderes espirituales de las comunidades indígenas de la Sierra Nevada de Santa Marta. A medida que avanza su aprendizaje, Cecilia comienza a incorporar el término "abuela” como designación de su rol comunitario y como indicador de su transformación étnica.

Es que ni siquiera nos daba la josca, nada de eso, y ya cuando empezamos a salir, que Carlos nos invitó a los pueblos y nos sentábamos toda la noche, entonces toda la noche escuchándolos a ellos, y escuchando todo eso que nos contaba, de todo eso que eran los indígenas y todo eso como que ya empieza... "Oiga, y nosotros porque estábamos tan cerradas", porque yo iba y le contaba a las otras abuelas y eso "ah, a usted qué le pasó, usted que se metió con John y con todos ellos", mis hermanos: "ustedes no entran sino a fumar marihuana", porque lo veían a uno. Ellos empezaron a mambear y toda esa cosa, fue más terrible cuando a ellos les dieron el hayo y el poporo. Ahí sí fue peor porque decían que yo me había vuelto marihuanera, porque desde el 2010 que le dieron el poporo, fue cuando comenzaron a darnos josca. Eso no se veía. Entonces claro, eso para nosotros fue nuevo pero, como digo yo, fue entrándole y entrándole, me fui quedando, me fui quedando y ya me gustaba cuando yo me decía: "abuela, nos vamos pa Sesquilé, nos vamos pa Cota, que pa Chía”. Y yo fui empezando así, a salir, a salir hasta hoy día que me conocen muchas personas, y así cuando no voy: "que la abuela, que donde está la abuela (Cecilia Chiguasuque, comunicación personal, septiembre 5 de 2015).

La designación de "abuela" marcaba paulatinamente en Cecilia su rol de sabedora indígena en la comunidad de Bosa. Sin embargo, Cecilia recuerda a sus jóvenes maestros hombres como reservados y 
con tendencia a no transmitir fácilmente la información aprendida de especialistas médicos indígenas que colaboraban con el proceso de fortalecimiento cultural en Bosa. Para ella era una muestra de cierto machismo, pues parecía que por ser mujer no podía ser parte de los "privilegiados" iniciados. Por esta razón, su camino a consolidarse legítimamente como sabedora no dejó de presentar obstáculos, enfrentamientos de poder con base en el género y, finalmente, metas logradas. $\mathrm{Al}$ inicio Cecilia acepta no estar muy identificada con la casa sagrada que habían construido en Bosa. Al asumir el cuidado de esta, más adelante, su estatus se transformó.

Entonces una vez yo me acuerdo que después de pasar ya un tiempo él ya me dio a mí las llaves del cusmuy, entonces él fue el que empezó a decirme "abuela", me dijo: "abuela, le voy a entregar las llaves”. Entonces yo le decía: "bueno, pero a mí me dice entonces como para que me las entrega, porque usted me dice que me entrega las llaves y yo no sé qué hacer con él”. Pero eso me las dio antes de irse el taita Orlando, porque el taita Orlando a las siete de la mañana estaba ahí, en cambio John a veces llegaba ocho, 8:30, y daba pena con el taita que estuviera afuera. Entonces él me entregó las llaves más que todo fue por eso, porque como nosotras si madrugábamos. Entonces yo me hice cargo de las llaves, llegaba temprano. Entonces John: “abuela, entonces usted ordena”, porque como ellos entraban y a veces se sentaban noches enteras entonces dejaban todo el reguero. "Entonces abuela usted levanta lo que haiga, enciende el fuego y hace seguir al taita Orlando mientras yo llego", y así lo hacíamos. Entonces una vez no me explicó y el taita Orlando empezó a hacer unos trabajos y trajo unos velones, a cada paciente le pedían un velón, y entonces ponían todos así en círculo. Ahí los dejaban, yo veía esos velones y a mí me pareció muy fácil coger todos y echarlos a la candela. A mí me pareció fácil eso, ese desorden ahí. Cuando yo llego me dijo: "abuela, ¿qué hizo todos los velones?” Y yo: "ahí los prendí”. "No abuela”. “¿Ustedes me explicaron que yo no podía coger eso?”. Y ellos ahí se dieron cuenta de que yo no lo hice por nada malo, sino porque ellos necesitaban 
que me dijeran. Y ahí empezamos: "bueno abuela, y después de las consultas quédese un rato y nos sentamos acá”. Y así, a veces me daba las nueve, las 10 de la noche ahí con ellos escuchándolos, yo solo escuchaba y cuando tenía una duda yo les preguntaba y ellos me contestaban, pero a veces no me contestaban bien y yo como que la embarraba: "ah, no, es que John me dijo esto". Y luego yo me decía: "pero es que esto no es así". Y yo: "ustedes no me explicaron bien". Esa fue la más embarrada que yo hice, después entendí que esos velones eran trabajo de ellos y que ya no los podía coger. Una vez también llevaban la piedra para hacer la cal, ¿yo qué iba a saber? A mí me pareció fácil fue limpiarla y yo no podía coger eso. Me pareció muy fácil una vez arrimarla al fuego y fue que se reventó. Cuando preguntaron que quien fue, pues “yo", "ustedes no me explicaron". Yo en eso si todavía peleo mucho porque John es muy desordenado, él ya sabe que si lo pone en su sitio pues se lo respetamos. O le digo: "Johncito, qué es lo que hay que hacer". John me dice: "esto abuela, que esto". Ah bueno. Y así es que uno va aprendiendo (Cecilia Chiguasuque, comunicación personal, septiembre 5 de 2015).

Para Cecilia, su proceso de ingreso y aprendizaje de la medicina la consolidó como líder comunitaria y afianzó su identidad como indígena. Como también hemos logrado comprender en el escenario de la etnicidad muisca, la identidad étnica se pone a prueba y se confronta mediante el encuentro intersubjetivo, mediante el encuentro con "otros" que convalidan la indigenidad al actuar como "pares" y legitimadores del discurso que fundamenta la indigenidad personal. Por esta razón, Cecilia recuerda escenarios donde su comunidad compartió con otros grupos indígenas como imágenes-recuerdo de la consolidación de su rol como mujer importante de la comunidad de Bosa.

Entonces en el cabildo mismo ya se dieron cuenta que a mí me gustaba todo eso, los encuentros, y a mí me mandaron a muchos sitios, yo estuve en el Ecuador, estuve en muchas comunidades y yo iba allá era solo a aprender. Solo a aprender, porque era muy poco 
lo que hablaba. A veces me daba temor hablar porque yo decía: “¿yo qué puedo hablar?” Y en una me acuerdo tanto que a mí me tocó en un encuentro que hubo muchas mujeres de muchos países. Entonces a mí Reinel, en ese tiempo era Reinel (el gobernador), me mandaron a ese encuentro por allá a un pueblo casi llegando a la frontera. Entonces nos mandaron allá y ni siquiera nos dijeron qué era lo que íbamos a hacer. Cuando allá, en primera lista la abuela del cabildo de Bosa. Le dije a Reinel: "¿qué voy a decir allá delante de todo ese montón de comunidad?, No eso no me salen palabras". Entonces ellos ya empezaron con el ambil. Entonces: "no abuela, chúpese este ambil”. Me dieron unas pepitas de hayuelo y no sé qué y "vaya y párese allá, sumercé ya ha andado mucho con los otros y ya sabe". No, yo me puse a hablar y hablaba, y hablaba, yo decía: "yo no soy yo". Yo me asustaba porque yo misma me escuchaba y dije: "oiga, pero yo desde cuándo estoy hablando así". Y yo cuando termine, que eso fue como una hora de solo hablar, cuando yo me bajé todos esos me aplaudieron y entonces yo llegué y le dije a Reinel, y hasta me abrazó y dijo: "Huy Ceci, muy bonito lo que usted dijo". "Pero yo no era Reinel”. Dijo: “¿Cómo así? Dije: "yo no era". Entonces otros: "si son los abuelos". Y empezaron hablar que los abuelos de espíritu, yo no entendía nada de esas cosas, yo no sabía que era espiritismo ni espiritual ni nada de esas cosas. Desde ahí yo dije: "si". Porque hasta donde me acuerdo a mí me daba hasta pena que alguien me dijera algo y yo temblaba, y ese día estaba tan segura. Desde ahí empecé a salir y hoy día me paro delante de mucha gente y hablo como en lo de la plaza de los artesanos y aquí en la Universidad Nacional (Cecilia Chiguasuque, comunicación personal, septiembre 5 de 2015).

La mujer que en un inicio se narraba como la niña temerosa de su mamá y de las gitanas, como sumisa en las labores del hogar del pasado bucólico y como una campesina más del altiplano cundiboyacense, ahora se narra como mujer indígena y sabedora de medicina. Del fragmento anterior es relevante resaltar dos elementos. En primer lugar, que Cecilia descubrió que mediante el poder de las plantas 
medicinales como el ambil (gelatina de tabaco) ella podía conectarse con los espíritus y hacer que hablaran por medio de sus palabras. En segundo lugar, que el ambil, acompañado del hayuelo, conforman una medicina netamente femenina que permite que en ese momento se haya fortalecido como oradora y transmisora de saberes. El poder femenino permanente en la complementariedad de los géneros en la preparación del ambil lo trataremos en el siguiente capítulo.

En suma, en este capítulo hemos identificado varios elementos. En primer lugar, que la llamada "memoria indígena", cuando es abordada desde los relatos de las mujeres, es cercana a la "memoria comunicativa" que se da en los espacios cotidianos y que se transmite de manera fluida, natural y espontánea; sin las pretensiones de los expertos y especialistas que buscan fijar la memoria oficial que se torna "cultural".

Aun así, identificamos tendencias en sus relatos. Unas corresponden a la prevalencia de ciertos lugares, objetos, acciones, relaciones, figuras, eventos y roles que se repiten constantemente en las historias de vida. Mediante estos elementos del relato es posible identificar imágenes-recuerdos que, al vincularse a las tendencias narrativas, se tornan imágenes-hábitos. Por eso los recuerdos particulares y específicos de las mujeres al mostrarse como comunes y recurrentes permiten la emergencia y consolidación de cartografías de eventos e imágenes habituales. A partir de tales repeticiones se instauran marcos comunes de narraciones, interpretaciones y juicios de valor que terminan aportando a la elaboración de la indigenidad muisca a partir de recuerdos de la vida bucólica y campesina de la Bogotá rural de antaño.

De esta manera, hemos identificado que el primer sustrato de la memoria muisca corresponde a las pequeñas historias y anécdotas transmitidas por las memorias y familias de la vida antigua, de sus paisajes, de sus hogares, de sus relaciones familiares, de género, de sus cultivos, alimentos, fiestas, agüeros, leyendas y de los valores y enseñanzas forjadas mediante la reflexión continua de tales recuerdos. Ese sustrato marca un primer marco temporal en las narraciones que se caracteriza, entre otras cosas, por la negación de la identidad indígena y la aceptación de una que oscila entre la "nativa" y la campesina.

El segundo sustrato corresponde al segundo marco temporal y marca un punto de giro en la indigenidad de las mujeres narradoras. 
Si seguimos entendiendo la indigenidad como una construcción discursiva de la identidad indígena, esta se asume de manera explícita cuando las historias dejan de narrar la vida bucólica y comienzan a contar la historia de las organizaciones comunitarias que dieron origen a los cabildos muiscas de Suba y Bosa. Es en ese momento cuando las mujeres, de acuerdo con su trayectoria y participación directa o indirecta en el proceso político-cultural, se preguntan si acaso no deben ser reconocidas como indígenas muiscas. La categoría étnica las confronta a sí mismas y a todos sus espacios sociales habituales.

Las historias también muestran que fueron personas de generaciones más recientes quienes terminaron por "indigenizar" a sus ancestros. Los abuelos y padres, en varias ocasiones no sabían de su condición étnica, por lo cual la identidad indígena se convirtió en un campo de confrontaciones, reflexiones y creaciones que hoy continúan tomando como base las imágenes-hábito de los ancianos. Por eso la identidad muisca yace inicialmente en los pequeños detalles de la vida cotidiana que han sido reproducidos familiar y comunitariamente.

Una vez aceptada la relación establecida entre la identidad indígena y su base campesina, las mujeres muiscas de hoy amplían su campo reflexivo y la indigenidad se torna más compleja, se alimenta de memorias de largo aliento materializadas en los mitos y en sus correspondientes conceptos, relaciones y valores. Es entonces cuando las mujeres establecen relaciones entre estas grandes estructuras narrativas-morales y los elementos culturales transmitidos generación tras generación. De esa manera, los trabajos en la cocina y el hogar, por ejemplo, comienzan a ser valorados en el marco de virtudes y cualidades otorgadas a las deidades femeninas; el rol de lo femenino se consolida principalmente en la gestación de vida y en su ordenamiento y cuidado.

En el siguiente capítulo abordaremos diferentes maneras en que mujeres indígenas elaboran sus interpretaciones históricas en torno al rol de la mujer en la historia de largo aliento del Pueblo Muisca y cómo fundamentan una serie de discursos y prácticas que podrían estar configurando una versión de feminismo indígena a partir del campo de representaciones que vincula la figura de la "matriz" con otros elementos propios del poder femenino, principalmente en las prácticas medicinales comunitarias. 
